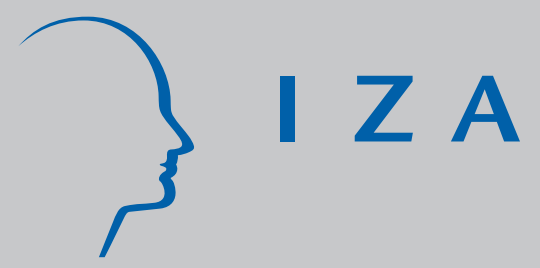

IZA DP No. 1167

Are Asian Migrants Discriminated Against in the Labour Market? A Case Study of Australia

P. N. (Raja) J unankar

Satya Paul

Wahida Yasmeen

J une 2004 


\title{
Are Asian Migrants Discriminated Against in the Labour Market? A Case Study of Australia
}

\author{
P. N. (Raja) Junankar \\ University of Western Sydney \\ and IZA Bonn \\ Satya Paul \\ University of Western Sydney \\ Wahida Yasmeen \\ University of Western Sydney
}

\author{
Discussion Paper No. 1167 \\ June 2004
}

\author{
IZA \\ P.O. Box 7240 \\ 53072 Bonn \\ Germany \\ Phone: +49-228-3894-0 \\ Fax: +49-228-3894-180 \\ Email: iza@iza.org
}

\begin{abstract}
Any opinions expressed here are those of the author(s) and not those of the institute. Research disseminated by IZA may include views on policy, but the institute itself takes no institutional policy positions.

The Institute for the Study of Labor (IZA) in Bonn is a local and virtual international research center and a place of communication between science, politics and business. IZA is an independent nonprofit company supported by Deutsche Post World Net. The center is associated with the University of Bonn and offers a stimulating research environment through its research networks, research support, and visitors and doctoral programs. IZA engages in (i) original and internationally competitive research in all fields of labor economics, (ii) development of policy concepts, and (iii) dissemination of research results and concepts to the interested public.
\end{abstract}

IZA Discussion Papers often represent preliminary work and are circulated to encourage discussion. Citation of such a paper should account for its provisional character. A revised version may be available on the IZA website (www.iza.org) or directly from the author. 
IZA Discussion Paper No. 1167

June 2004

\section{ABSTRACT}

\section{Are Asian Migrants Discriminated Against in the Labour Market? A Case Study of Australia}

This paper explores the issue of discrimination against Asian migrants in the Australian labour market using a unique panel data set, the Longitudinal Survey of Immigrants to Australia (LSIA). This paper estimates models of the probability of being unemployed for Asian and non-Asian migrants controlling for various characteristics including age, education, and English language ability. More importantly, we control for the visa status of the migrants. Our results suggest that there are significant "unexplained differences" for males that may be ascribed to "discrimination" against Asian migrants. However, the results for females are mixed: the evidence suggests that Asian females do worse than non-Asian females only in the first year after arrival.

JEL Classification: J7, J61, J64, J31

Keywords: immigrants, discrimination, unemployment, mobility, wage differentials

Corresponding author:

P.N. (Raja) Junankar

School of Economics and Finance

University of Western Sydney

Campbelltown Campus

Locked Bag 1797

Penrith South DC

NSW 1797

Australia

Email: raja.junankar@uws.edu.au 


\section{Are Asian Migrants Discriminated Against in the Labour Market? A Case Study of Australia ${ }^{1}$}

\section{Introduction}

Discrimination against Asian migrants in the Australian labour market is explored using a unique panel data set, the Longitudinal Survey of Immigrants to Australia (LSIA). Following on from the classic papers of Phelps (1972), Arrow (1973) and Becker (1957), the discussion begins by looking at discrimination in the labour market and the problems involved in estimating its extent. Much earlier literature has focussed on wage discrimination, however, the arguments put forward here are based on assessing the extent of discrimination in finding employment. In our view, most of the wage studies underestimate the extent of discrimination as many members of the discriminated group do not find employment in the first place and have no wage.

In the study, models of the probability of being unemployed are estimated with an allowance for differences between Asian and non-Asian migrants controlling for a set of individual characteristics. Most of the earlier Australian economics research has focussed on differences between English speaking migrants and non-English speaking background migrants (NESB migrants) without also distinguishing between migrants from (say) the Netherlands or from (say) Vietnam². In this study the focus is on discrimination against "people of colour", in particular Asian migrants relative to other migrants. Clearly there are problems involved in ascribing all the differences between Asian migrants and other migrants to discrimination however, the study aimed to control for most of the variables that are likely to affect labour market success.

The following sections provide a description of the LSIA data, descriptive statistics about labour market outcomes, econometric estimates using probit estimation, and a detailed analysis decomposing the differences of unemployment probabilities between Asian and non-Asian migrants. The results suggest there are significant "unexplained differences" for males (and for females only in their first year) that may be ascribed to discrimination against Asian migrants. In conclusion, suggestions are offered for some much needed future work in this field.

\footnotetext{
${ }^{1}$ We are grateful to the Department of Immigration and Multicultural Affairs for providing us with the data set and to David Osborne and his colleagues for their assistance with the documentation etc. We are also grateful for financial assistance to the University of Western Sydney in supporting this research. Earlier versions of this paper were presented to the Economics Seminar at the Research School of Social Sciences, Australian National University, the 2001 Econometric Society Australasian Meeting, University of Auckland, the Far Eastern Meeting of the Econometrics Society, Kobe, Japan, the University of Melbourne, and the IZA in Bonn. We are grateful for all the comments by participants that helped to improve this version of the paper. We also thank Mark Wooden and Lou Will for their comments on an earlier version of the paper. They are not responsib le for remaining errors.

2 With the notable exception of a recent paper by Borooah and Mangan (2002) which discusses the disadvantage faced by Asians and indigenous people in their occupational status. The British have studied this question extensively and a recent paper by Blackaby et al. (2002) has many similarities with our study. See also the references cited therein.
} 


\section{Main hypotheses/Models}

The main aim of this paper is to see whether there is discrimination against Asian migrants (or visible minorities). It is motivated by a vast difference that exists in unemployment rates between Asian and non-Asian migrants. For instance, in 1996 the unemployment rate among Asian migrants, who arrived during 1991-1996, was 23 per cent as against 15 per cent among their non-Asian counterparts. Asian migrants who arrived during 1986 -1990 showed an unemployment rate of 12.1 per cent. The corresponding figure for non-Asians was 7.3 percent $^{3}$. Our preliminary analysis of the data from Wave 1, Wave 2 and Wave 3 of LSIA (1993-1995) depict a similar picture. The unemployment rates among Asian born migrants are 47.1 percent after six months of their arrival (Wave 1), 28.4 per cent after eighteen months of arrival (Wave 2) and 18.3 per cent after thirty months of their arrival (Wave 3) in Australia. The corresponding figures for non-Asian migrants are relatively low: 29.0, 15.3 and 10.4 per cent respectively (see Table 1).

Discrimination entails different treatment of a group of people who have identical qualifications, experience, skills, etc. Differences in outcomes for two different groups may come about because they have differences in various human capital characteristics or because the groups have different preferences. Differences may also arise due to differences in the quality of measured variables, for example, education. In addition, differences may occur because employers may discriminate against a particular group.

This discrimination may be due to what Becker (1957) calls employer's "taste" or it could be because employers are concerned that their employees may not wish to work with the discriminated group or because the employer believes the customer/client may not wish to deal with that group. Discrimination based on taste could only occur if the firm is willing to forgo a certain part of their profits to satisfy their tastes for discrimination. Clearly, in a competitive ndustry where there are no rents firms would be unable to discriminate. Hence, discrimination is only possible where rents exist, that is where there are elements of non-competitive behaviour. There is also a literature on so-called "statistical discrimination", Arrow (1973), where employers in a market with imperfect information may use some visible characteristic to discriminate on the basis of some past experience.

It is of course possible that we may find that there are significant differences between two groups that may simply be due to a poorly specified model that excludes an important variable. It is common in studies of race and gender, see Altonji and Blank (1999), that we try to explain (say) wages in terms of a set of demographic and human capital characteristics and then ascribe any unexplained differences to discrimination.

In this paper we define labour market success as being employed (or lack of success as being unemployed). If Asian migrants were being discriminated against we would, ceteris paribus, expect them to have a higher probability of being unemployed. In usual labour market models we hypothesise that the probability of unemployment is a joint probability of being offered a job and accepting the offer. The offer of a job is dependent on the employer's expectation of the productivity of the potential employee that would depend on measurable characteristics like age, education, experience, etc. and perhaps on their taste for discrimination. The probability of accepting an offer would depend on the reservation wage of the potential employee that would depend on his/her preference for leisure and

\footnotetext{
${ }^{3}$ See Australian Bureau of Statistics (1996).
} 
outside options in terms of wealth, social security benefits etc. We estimate a reduced form equation for the probability of being unemployed (as is common in the literature) as we cannot identify the separate equations. 


\section{Some Evidence from Previous Studies}

There are several papers that compare the success of migrants relative to Australian born people in the labour market (see, for example, Miller (1982), Inglis and Stromback (1984), Wooden et al (1994), Chapman and Miller (1985), Wooden and Robertson (1989), Foster et al. (1991), Beggs and Chapman (1990), Chapman and Salvage (1994), Will (1997), Cobb-Clark and Chapman (1999) and Le and Miller (2000)).

As mentioned earlier most studies of migrants in Australia have compared Non-English Speaking Background (NESB) migrants with English Speaking Background (ESB) migrants, see Wooden (1994) for a review of the literature. One exception to this literature is a paper by Evans and Kelley (1986) (using data from the public use sample of the 1981 Australian Census) that is concerned with discrimination in the Australian labour market using occupational status as the dependent variable. They find that migrants from Mediterranean countries who were educated overseas performed worse than other migrants or native born Australians. A recent paper by Borooah and Mangan (2002) explicitly study the differences between Asians and non-Asian occupational status and find that Asians are at a disadvantage in the labour market compared to non-Asians. A study by Wooden (1991) looks at the experience of refugees in the labour market and does separate out the ESB and NESB into country groups by introducing shift dummies ${ }^{4}$. However, this does not allow for differences between different groups for various characteristics. Again most studies have concentrated on estimating wage equations, Chapman and Salvage (1994), although a few have explored the probability of migrants facing unemployment in the early phases of their arrival in Australia, Miller (1986).

Borjas (1994) provides a detailed review of literature on the success of migrants in (especially) the US labour market where most of the studies have focussed on earnings functions, and a few have compared wage differences between ethnic groups (Asians/Hispanics/Whites). Chiswick (1983) has compared earnings of Asian Americans with the rest and found that they have higher earnings than whites. However, we focus on discrimination in finding employment: estimates of discrimination based on studies of earnings are likely to be underestimates as they usually ignore the probability of finding employment in the first place. ${ }^{5}$

A big concern in the US literature has been on the assimilation of migrants into the US labour market, see for example Lalonde and Topel (1991). Assimilation has been understood to be either a convergence of migrant wage rates to native wages or a convergence of migrant earnings over time (the latter could be simply because migrants work longer hours). In these cross section studies there are potential problems of confusing earnings of different cohorts that may give the impression of assimilation in the US. Borjas (1994) in summarising his earlier work argues that if the earlier cohorts arriving in the US were higher quality (productivity) migrants than more recent ones, a cross section study that includes a variable "years of residence" would give a misleading result of assimilation. In our study we do not focus on wages or earnings, but in any case

\footnotetext{
4 See, also, VandenHeuevel and Wooden (2000).

5 There are numerous studies of wage discrimination, often gender based, see Becker (1957), Arrow (1973, 1998), Oaxaca (1973), Chiswick (1983), Evans and Kelley (1986), Oaxaca and Ransom (1994), Borjas (1994, 1999), Hum and Simpson (1999, 2000), Kidd and Meng (1997), Blau and Kahn (1998), Darity (1998), Heckman (1998), Altonji and Blank (1999) and Silber and Weber (1999).
} 
since we are dealing with one cohort this problem would not affect our analysis. In our study we see if there are improvements in the probabilities of labour market success of Asian migrants relative to non-Asian migrants over time.

In some recent work Hum and Simpson (1999 and 2000) using Canadian longitudinal data (Survey of Labour and Income Dynamics, SLID) estimate earnings functions and allow for discrimination against visible minorities (migrants of colour). In the first paper they use cross-section data from the first Wave to estimate wage equations allowing for intercept differences (and interactive dummies) between different ethnic groups. In particular, they use a Heckman correction for the probability of employment in their wage equations and find that even after controlling for the usual human capital variables there are significant differences between the wages of "visible minorities" and the rest. In a subsequent paper they consider the issue of assimilation and find that visible minorities' wages do not converge to that of native Canadians. These results suggest that there is a form of discrimination against visible minorities in the Canadian labour market. Our paper is an attempt to provide some evidence using Australian longitudinal data on discrimination against Asian migrants.

In an important paper exploring the success of migrants who have entered under different visa categories (Family, Skilled, Humanitarian), Cobb-Clark (2000) estimates the probability of participating in the labour market and (conditional on participating) the probability of employment. She uses data from Waves 1 and 2 of the LSIA data set for her analyses. She finds that (surprisingly) education is not an important explanatory variable although English language ability plays an important role. However, curiously males who improved their English worsened their employment probabilities! Compared to the economic skills migrants (Business Skills/Employer Nominated Scheme) all other visa categories do worse, especially the Humanitarian category. In the second Wave most visa category employment prospects improve although the Humanitarian category does not improve as much and the gap widens between them and the rest. Migrants who visited Australia prior to migrating had a higher probability of being employed perhaps because they had a better knowledge of employment opportunities (presumably those visitors who thought that they would not find suitable employment decided not to migrate).

In a recent paper Blackaby et al. (2002) study the question of earnings and employment differentials for ethnic (non-white) groups in Britain. They find that ethnic minorities (even second generation migrants) do significantly worse than the native British population. In particular, there are significant differences in the employment probabilities.

\section{The Longitudinal Survey of Immigrants to Australia: Description of Sample}

The Longitudinal Survey of Immigrants to Australia (LSIA) was conducted to inform policy makers about the settlement process of immigrants to Australia ${ }^{6}$. The sample is a stratified random sample of all Principal Applicants aged 15 years and over who arrived in Australia between September 1993 and August 1995. The first wave of interviews were in March 1994, the second wave in March 1995, and the third wave in March 1997 (each wave of interviews was spread out over two years). In the first wave a total of 5192 Principal Applicants were interviewed. In wave 2 the sample had fallen to 4469 Principal Applicants. Wave 3 consisted of 3752 Principal Applicants.

\footnotetext{
${ }^{6}$ See Williams et al. (1997) for some early results from this survey.
} 
Besides the usual demographic information this data set contains information on education, English language ability, some information about previous labour market experience, and the visa category under which the principal applicant was admitted. In our analysis we have limited our sample to principal applicants as that provides us with information about the visa conditions for their entry into Australia. As the data are for migrants who arrived between September 1993 and August 1995 as principal applicants they would all have been selected on a points basis which emphasises age, education, and skills except for special cases like family migrant and the humanitarian (refugee) categories. This is one of the few data sets on migrants in Australia where we have information on the visa category under which they entered the country.

Migrants are admitted under five categories: (i) Business Skills/ Employer Nomination Scheme, (ii) Preferential Family, (iii) Concessional Family, (iv) Independent, and (v) Humanitarian grounds or Refugees. Migrants who are selected entirely on the basis of close family relationship are categorised as Preferential Family migrants. Skill-based migrants who are selected without family relationship are classified as Independent; and migrants with offers of employment before migration are classified as Employer Nomination Scheme. Those who are selected on the basis of skills and distinct family relationship are Concessional Family migrants. Migrants who meet certain capital requirements are classified as Business Skills migrants.

Since we would expect migrants who entered on an employer nominated scheme (ENS) to find employment immediately on arrival we can control for this variable. Similarly, we would expect refugees not to have been screened on the basis of their employability (using English language, education, skills, experience, etc.) we can control for them to have a lower success rate in the labour market.

All applicants entered the labour market roughly at the same time and hence we do not have some of the problems of confounding cohort effects with other aspects. The period 1993-95 was a period when employment was growing and unemployment was declining gradually.

In this paper we are concerned with the success or failure of Asian migrants in finding employment conditional on being in the labour force ${ }^{7}$. The analysis is restricted to the principal applicants who are in the labour force, that is, the individuals who are employed or unemployed and looking for a job. Employed persons are those who are earning a wage or salary, conducting their own business and other employed. Unemployed are the individuals looking for a full time or part time job.

There is self-reported information about the English speaking ability of the Principal Applicants in the LSIA. There are five categories: (i) Speak English only (as their first language) or best, (ii) Very Well, (iii) Well, (iv) Not Well, or (v) Not at all.

Asians are defined as those migrants from South Asia (Indian subcontinent), East and Southeast Asian (China, Korea, Vietnam etc.), as well as (using common Department of Immigration and Multicultural Affairs definitions) from the Middle East or North Africa

\footnotetext{
${ }^{7}$ In our estimation we have not corrected for possible selection bias. Given our data set it is not possible to find variables that would affect the participation decision but not affect the probability of being unemployed. Our results are therefore conditional on being in the labour force.
} 
(Turkey, Egypt, Iran, Iraq etc). The sample size for Asians in the first wave is 2648. Among the non-Asians we include all migrants from Europe, both NESB (Poland, Russian Federation, Ukraine etc.) and ESB (U.K., Ireland etc.), North and South America and Africa (excluding North Africa), a total of 2544 in the first wave. In the second wave the sample size for Asians and non-Asians becomes 2263 and 2206, respectively. In the last or third wave the number of respondents reduces to 1903 and 1849 Asians and nonAsians, respectively.

\section{A Preliminary Analysis of the LSIA}

Table 1 provides summary information on some key characteristics of Asian and nonAsian migrants interviewed in Wave 1, Wave 2 and Wave 3. The table reveals some significant similarities as well as differences between the two groups. Non-Asian migrants seem to have an advantage over Asian migrants in terms of their ability to speak English well. Not surprisingly since the non-Asians include the British, about $49 \%$ of non-Asians could speak English 'best', whereas among Asian migrants only 18\% could do so. About one-third of Asian migrants either cannot speak English at all or speak very poorly, whereas the figure for non-Asian migrants is about one-sixth.

About half of the non-Asian migrants visited Australia prior to their migration, the corresponding figure for Asian migrants is about two-fifths. The distribution of Asian migrants by the level of education seems to be different from that of non-Asian migrants. For instance, the proportion of degree holders in the Asian migrants is higher than that in non-Asian migrants.

The distribution of Asian migrants by visa category is broadly similar to that of non-Asian migrants. About $75 \%$ of migrants are married, and there is little difference between them in terms of their average age.

There are significant differences in participation rates between Asian and non-Asian migrants. The participation rates among Asian male and female migrants are lower than their non-Asian counterparts. See Cobb-Clark (2000) for a further discussion of this issue. As the migrants live longer in the country, they acquire more information about the labour market and thus improve their participation rates.

As mentioned earlier, there are also significant differences in the unemployment rates between Asian and non-Asian migrant groups ${ }^{8}$. Unemployment rates among Asian male and female migrants are about $50 \%$ higher than their non-Asian counterparts in each Wave of the survey. This could be due to differences in their human capital and other characteristics or due to discrimination or due to both. This issue will be explored in subsequent sections.

It is also worth noting that the unemployment rates decline sharply amongst both groups of migrants. After 30 months of their migration to Australia, the unemployment rate among non-Asian migrants converges approximately to the national average (9\%) but the unemployment rate among Asian migrants is twice the national average. It seems that the head-start disadvantage in terms of high unemployment rates that Asian migrants have

\footnotetext{
${ }^{8}$ Second, the non-response rate from unemployed Asian and non-Asian migrants is very high and almost identical in Wave 2 and Wave 3 of the Survey.
} 
either due to discrimination or other reasons does not disappear at least in the short run. Longitudinal data for a period longer than that covered by the present survey are needed to explore this issue further. 
Table 1

Characteristics of Migrants

\begin{tabular}{|c|c|c|c|c|c|c|c|c|c|}
\hline \multirow[t]{2}{*}{ Characteristics } & \multicolumn{3}{|c|}{ Asian Migrants } & \multicolumn{3}{|c|}{ Non-Asian Migrants } & \multicolumn{3}{|c|}{ All Migrants } \\
\hline & $\mathrm{M}$ & $\mathrm{F}$ & $\mathrm{M}+\mathrm{F}$ & $\mathrm{M}$ & $\mathrm{F}$ & $\mathrm{M}+\mathrm{F}$ & $\mathrm{M}$ & $\mathrm{F}$ & $\mathrm{M}+\mathrm{F}$ \\
\hline Sample Size (persons) & & & & & & & & & \\
\hline Wave 1 & 1450 & 1115 & 2565 & 1508 & 1119 & 2627 & 2958 & 2234 & 5192 \\
\hline Wave 2 & 1237 & 950 & 2187 & 1316 & 966 & 2282 & 2553 & 1916 & 4469 \\
\hline Wave 3 & 1041 & 800 & 1841 & 1119 & 792 & 1911 & 2160 & 1592 & 3752 \\
\hline \multicolumn{10}{|l|}{ Labour Force } \\
\hline Wave 1 & 1036 & 428 & 1464 & 1138 & 482 & 1620 & 2174 & 910 & 3084 \\
\hline Wave 2 & 965 & 381 & 1346 & 1089 & 468 & 1557 & 2054 & 849 & 2903 \\
\hline Wave 3 & 859 & 379 & 1238 & 965 & 411 & 1376 & 1824 & 790 & 2614 \\
\hline \multicolumn{10}{|l|}{ Participation Rate (\%) } \\
\hline Wave 1 & 71.4 & 38.4 & 57.1 & 75.5 & 43.1 & 61.7 & 73.5 & 40.7 & 59.4 \\
\hline Wave 2 & 78.0 & 40.1 & 61.5 & 82.7 & 48.4 & 68.2 & 80.4 & 44.3 & 65.0 \\
\hline Wave 3 & 82.2 & 47.4 & 67.2 & 86.2 & 51.9 & 72.0 & 84.4 & 49.6 & 69.7 \\
\hline \multicolumn{10}{|l|}{ Unemployment Rate (\%) } \\
\hline Wave 1 & 46.1 & 49.1 & 47.1 & 28.2 & 30.9 & 29.0 & 36.7 & 39.7 & 37.6 \\
\hline Wave 2 & 28.7 & 27.6 & 28.4 & 14.6 & 16.9 & 15.3 & 21.2 & 21.7 & 21.4 \\
\hline Wave 3 & 17.3 & 20.3 & 18.3 & 9.2 & 13.1 & 10.4 & 13.0 & 16.6 & 14.1 \\
\hline Average. Age (yrs.) & 34 & 32 & 33 & 36 & 36 & 36 & 35 & 34 & 35 \\
\hline Visited Australia (\%) & 34.5 & 35.2 & 34.8 & 53.2 & 51.5 & 52.5 & 44.0 & 43.4 & 43.8 \\
\hline \multicolumn{10}{|c|}{ Distribution by English Speaking Ability $(\%)$} \\
\hline Best & $16.9^{\circ}$ & 19.2 & 17.6 & 49.8 & 47.1 & 49.0 & 33.8 & 32.9 & 33.6 \\
\hline Very well & 18.1 & 16.0 & 17.5 & 12.5 & 19.9 & 14.6 & 15.2 & 17.9 & 16.0 \\
\hline Well & 31.0 & 35.7 & 32.4 & 19.1 & 17.4 & 18.6 & 24.9 & 26.7 & 25.4 \\
\hline Poor & 27.6 & 22.1 & 26.0 & 14.4 & 12.4 & 13.9 & 20.9 & 17.4 & 19.8 \\
\hline Not at all & 6.4 & 7.0 & 6.5 & 4.2 & 3.2 & 3.9 & 5.2 & 5.1 & 5.2 \\
\hline Married (\%) & 72.7 & 79.4 & 75.6 & 77.4 & 78.5 & 77.9 & 75.1 & 79.0 & 76.8 \\
\hline \multicolumn{10}{|c|}{ Distribution by Visa Status Category (\%) } \\
\hline Preferential family & 25.9 & 59.9 & 40.7 & 30.8 & 61.4 & 43.9 & 28.4 & 60.6 & 42.3 \\
\hline Concessional Family & 21.6 & 11.4 & 17.2 & 17.4 & 6.7 & 12.8 & 19.5 & 9.0 & 15.0 \\
\hline Independent & 20.7 & 10.6 & 16.3 & 19.7 & 12.2 & 16.5 & 20.2 & 11.4 & 16.4 \\
\hline Refugee & 19.2 & 13.6 & 16.8 & 15.1 & 15.6 & 15.3 & 17.0 & 14.6 & 16.0 \\
\hline Business Skill & 12.6 & 4.5 & 9.0 & 17.0 & 4.1 & 11.5 & 14.9 & 4.4 & 10.3 \\
\hline \multicolumn{10}{|c|}{ Distribution by Educational Level (\%) } \\
\hline Degree and above & 44.4 & 38.9 & 42.0 & 38.6 & 31.8 & 35.7 & 41.4 & 35.4 & 38.8 \\
\hline Technical & 23.5 & 16.5 & 20.4 & 39.1 & 31.2 & 35.8 & 31.5 & 23.9 & 28.2 \\
\hline Others & 32.1 & 44.6 & 37.6 & 22.3 & 37.0 & 28.5 & 27.1 & 40.7 & 33.0 \\
\hline
\end{tabular}

Source: LSIA. Authors' calculations. $\mathrm{M}$ and $\mathrm{F}$ stand for males and females respectively. 


\section{Econometric Analysis of Labour Market Success of Asian Migrants}

Since we are estimating the probability of being unemployed, conditional on being in the labour force, there may be some selectivity problems that may affect the results. Further, we estimate a reduced form equation of the probability of receiving an offer and not accepting it, or the probability of not receiving an offer. Unfortunately we cannot identify the separate probabilities.

This section models the probability of being unemployed in Wave 1, Wave 2, and Wave 3 taken separately. Ideally, we could pool the data set and use fixed effects estimation to control for heterogeneity. Since we are using probit estimation there are problems with using fixed effects as it leads to inconsistent estimates ${ }^{9}$. Further, since the time period between different Waves of the Survey is fairly short most of the explanatory variables are fixed over the sample period so we cannot use fixed effects with logit estimation. In addition, we would lose observations due to attrition and non-response problems. As such we have estimated our models for each Wave separately.

To explain the probability of being unemployed we used education as a human capital variable (but we did not have a good measure of experience ${ }^{10}$ ), English language ability, demographic variables and a variable to capture the screening effects before entry was granted to Australia (visa category). In an earlier phase of our research we had used dummies for occupation prior to migration but the estimates were insignificant. In addition we used State Dummies to allow for different industry/occupation demands for labour in different States. Precise definitions of the explanatory variables used in our estimation are given in Appendix 1.

To focus on our variable of interest we introduced a zero-one Dummy for migrants coming from Asian countries ${ }^{11}$. In all our estimations the procedure we followed was to allow for a simple intercept Dummy for Asian and then interacted the Dummy with all the explanatory variables. This allowed us to test for differences in the intercepts and slopes of the explanatory variables. We estimated separate equations for males and females, as we found significant differences in preliminary estimation.

The probability of migrant $\mathrm{i}$ being unemployed in Wave $\mathrm{t}$ is assumed to be given by:

$$
\operatorname{Pr}\left(U_{i(t)} \mid X_{i(t)}\right)=\Phi\left(X_{i(t)} \beta_{(t)}\right)
$$

where $\Phi$ is the standard normal cumulative distribution function. $U=1$ if the migrant $i$ is unemployed in Wave t, 0 otherwise. $X_{(t)}$ is a vector of human capital characteristics (education, English ability, visit to Australia prior to migration), demographic and geographic variables (age, marital status, State of residence) and Asian intercept and interaction dummies, which enable us to test the following hypothesis:

\footnotetext{
${ }^{9}$ See Baltagi (1995), Chapter 10.

${ }^{10}$ Since our data are on a disparate group of migrants with very different educational and employment backgrounds, the usual Mincer experience variable (Age - Years of Education - 5) is likely to be a very poor measure.

${ }^{11}$ Ideally, we would like to have a variable to capture "visible minorities" or people of colour. We simply have country of origin, and we should include people from Africa, but most of the migrants from South Africa or Zimbabwe are probably white. In future research we plan to see if we can explore this dimension further.
} 


$$
\mathrm{H}_{0(\mathrm{t})}=\text { There is no difference between Asian and non-Asian migrants. }
$$

The details of variables are given in the Appendix 1.

Since we have three Waves of data from the LSIA we can see how Asian migrants fare relative to non-Asian migrants over the period of study. If it were simply that Asian migrants have poorer English language ability and poorer information networks then as their knowledge of the Australian labour market improves they should become more like the non-Asians, ceteris paribus.

It is common in labour market analysis to study gender wage differentials or differences between the probabilities of employment or unemployment (see Cobb-Clark, 2000). However, our main focus of inquiry is whether there is a significant difference in the labour market for Asians and non-Asians. If we find that there are significant differences and that Asians have a higher probability of being unemployed, controlling for important characteristics, then we consider that to be prima facie evidence for "discrimination"12, see Altonji and Blank (1999). In a final section we discuss some of the possible reasons why the differences may not be due to discrimination but to other factors.

As mentioned earlier we estimated probit models for each gender allowing for intercept and slope differences between Asian and non-Asians. In Table 2 we present significance tests for differences between Asian and non-Asians. All equations were estimated using STATA version 6 and all standard errors provided are corrected for heteroscedasticity (White corrected standard errors). The detailed results are presented in Appendix Tables A1 through A3, and Table A4 provides the marginal effects derived from the probit estimation. For continuous (cardinal) variables these marginal effects are evaluated at the means while for dichotomous variables they are derived for a unit change in the variable.

Table 2

\section{Significance tests of Asian Dummies (Estimates of $\chi^{2}$ )}

\begin{tabular}{|l|l|l|}
\hline & Males & Females \\
\cline { 2 - 3 } & $\chi^{2}($ d.f) & $\chi^{2}($ d.f $)$ \\
\hline Wave 1 & $48.66^{*}(21)$ & $29.79^{*}(16)$ \\
\hline Wave 2 & $40.02^{*}(19)$ & $20.98(19)$ \\
\hline Wave 3 & $29.10^{* *}(17)$ & $13.15(17)$ \\
\hline \multicolumn{2}{|l|}{ Note: Parentheses contain the degrees of freedom. * and ** indicate significant }
\end{tabular}

at 1 and 5 percent levels respectively.

These results in Table 2 clearly show that there are significant differences for males between Asians and non-Asians when we control for a range of important characteristics that would affect labour market success. For females, we find a significant difference between Asians and non-Asians only in Wave 1 of the LSIA. In particular, we have controlled for human capital (education variables, English language ability), age, marital status, whether they had prior knowledge of the Australian labour market (as proxied by previous visit to Australia), and visa status. In addition, we also try to control for demand effects by allowing differences between different States, although these variable were not always significant. It is curious that the education variables are usually not significant,

\footnotetext{
${ }^{12}$ If the reader prefers, s/he may replace the word "discrimination" by "unexplained differences".
} 
perhaps because the Visa category and English language ability are correlated with education. Our results are similar to Cobb-Clark (2000) where the education variables are usually not significant. To test for this possibility we re-estimated the same equations separately for each visa category. Our results were substantially unchanged with education variables remaining (in general) insignificant ${ }^{13}$.

Appendix Table A 4 provides estimates of the marginal probabilities. The results show that the probability of unemployment increases with age. We had allowed for a quadratic term in age, but it was not statistically significant. Not surprisingly, the effect of good English speaking ability is to decrease the probability of being unemployed. It is interesting to note that the intercept dummy for Asians is not significant in the unemployment equations when taken independently. Migrants who have visited Australia prior to migration are less likely to be unemployed. These results support the findings of Cobb-Clark (2000) where she finds that migrants who visited Australia are more likely to be employed in both Waves 1 and 2 compared to the migrants who come for the first time to Australia.

It is important to note that we have controlled for English language ability (which is the usual reason given for NESB migrants showing poorer performance in the labour market). What we find is that good English language ability decreases the probability of being unemployed. Since we control for English speaking ability the poorer labour market prospects for Asians cannot be due to language difficulties.

Similarly, we have controlled for the different visa categories under which the migrants entered Australia. Clearly, as demonstrated in Cobb-Clark (2000), there are significant differences between the probability of being unemployed for different groups. Humanitarian visa category people (refugees) who would have not been screened on the basis of English language ability, skills, education, etc. would have a higher risk of unemployment compared to the Employer Nominated Scheme visa holders. Similarly, migrants coming to join their families have greater difficulties in the labour market. That exactly confirms our findings for the probability of being unemployed.

There was some evidence that demand factors, as proxied by State of residence, affects the probabilities of unemployment. Several of the state dummies are significant.

One of the main features to stand out is the consistency of the results when we test for differences between Asians and non-Asians: in all cases we find that we reject the joint hypothesis of equality of coefficients for males. However, for females we find that the differences are significant only in Wave 1.

We also carried out similar tests where we compared Asians (as defined above) with nonAsians who were defined as migrants from Europe and North America (i.e. excluding migrants from Africa and South America). The results for these tests were substantially the same as those described in this paper.

To investigate the differences between Asian and non-Asian migrants further we carried out a decomposition analysis in the next section.

\footnotetext{
${ }^{13}$ We thank Bruce Chapman for suggesting this test.
} 


\section{The Unemployment Gap: A Decomposition Analysis}

It is common in wage discrimination studies to decompose the differences between two groups in terms of the explained differences due to different characteristics (say human capital differences) and the differences that are due to differences in the impact of the different variables in terms of different estimated parameters, the beta vector, see Oaxaca (1973). Most studies of discrimination focus on wage differentials and log earnings equations are estimated. Using the mean values of the explanatory variables (the $\mathrm{X}$ vector) it is possible to explain part of the differences between the two groups. The decomposition is usually carried out as follows:

$$
\bar{W}_{1}-\bar{W}_{2}=\left(\bar{X}_{1}-\bar{X}_{2}\right) \hat{\beta}_{1}+\left(\hat{\beta}_{1}-\hat{\beta}_{2}\right) \bar{X}_{2}
$$

Where the W's are the mean log earnings of groups 1 and 2 respectively and the $\beta$ 's are the respective estimated coefficients (where group 1 is often treated as the norm, e.g. whites, or males). The first term on the right hand side is called the explained differences, that is the difference between the two groups that can be explained by differences in the mean values of the characteristics of the two groups. The second term on the right hand side is called the "unexplained differences" or "discrimination": that is differences that are due to the differential impacts of the $\mathrm{X}$ vector on the mean wages. Of course, the unexplained differences could be larger because an omitted variable which is correlated with the X's would affect the parameter estimates, the $\beta$ 's. In addition, in general, the X's may have been affected by prior discrimination as well so that even the explained differences may be affected by discrimination. However, in the case of these log linear estimations the means of the X's may be a useful way of estimating discrimination. But in our case of non-linear equations (probit estimates) there is no obvious analogue.

The approach followed in this paper is as follows. First, we calculate the average probability of unemployment for both Asian and non-Asian migrants and then decompose the gap into two components, firstly associated with differences in their characteristics, and secondly with differences in their impacts, see Doiron and Ridell (1994) and Blackaby et al. (2002). That is,

$$
\begin{aligned}
& \bar{\mu}_{a j(t)}-\bar{\mu}_{n j(t)}=\left(\tilde{\mu}_{a j(t)}-\bar{\mu}_{n j(t)}\right)+\left(\bar{\mu}_{a j(t)}-\tilde{\mu}_{a j(t)}\right) \quad \mathrm{j}=\mathrm{m}(\text { males }), \mathrm{f}(\text { females }) \\
& \bar{\mu}_{\mathrm{aj}(\mathrm{t})}=\frac{1}{\mathrm{~N}_{\mathrm{a}}} \sum_{\mathrm{i}=1}^{\mathrm{N}_{\mathrm{a}}} \Phi\left(\mathrm{X}_{\mathrm{iaj}(\mathrm{t})} \hat{\beta}_{\mathrm{aj}(\mathrm{t})}\right) \\
& \bar{\mu}_{\mathrm{nj}(\mathrm{t})}=\frac{1}{\mathrm{~N}_{\mathrm{n}}} \sum_{\mathrm{i}=1}^{\mathrm{N}_{\mathrm{n}}} \Phi\left(\mathrm{X}_{\mathrm{inj}(\mathrm{t})} \hat{\beta}_{\mathrm{nj}(\mathrm{t})}\right)
\end{aligned}
$$

and

$\tilde{\mu}_{\mathrm{aj}(\mathrm{t})}=\frac{1}{\mathrm{~N}_{\mathrm{a}}} \sum_{\mathrm{i}=1}^{\mathrm{N}_{\mathrm{a}}} \Phi\left(\mathrm{X}_{\mathrm{iaj}(\mathrm{t})} \hat{\beta}_{\mathrm{nj}(\mathrm{t})}\right)$

where for Wave $t, \bar{\mu}_{\mathrm{aj}(\mathrm{t})}$ and $\bar{\mu}_{\mathrm{nj}(\mathrm{t})}$ are the average (predicted) probabilities of unemployment for Asian and non-Asian migrants of gender $\mathrm{j}$; and $\widetilde{\mu}_{\mathrm{aj}(\mathrm{t})}$ is the average probability of unemployment for Asian migrants of gender $\mathrm{j}$ that would be predicted if 
each Asian migrant of gender $\mathrm{j}$ retained its characteristics but the impacts of these characteristics on probability were those estimated for non-Asian migrants. The first term on the right hand side of equation (3) represents the portion of the gap associated with differences in characteristics that influence the probability of unemployment. The second term is associated with differences in the impact of these characteristics on the probability of unemployment. Following the Oaxaca (1973) tradition, this term is called discrimination or "unexplained differences". A positive value for this term would indicate that Asian migrants of gender $\mathrm{j}$ are being discriminated against in the labour market relative to non-Asian migrants. A negative value would mean discrimination in favour of Asian migrants.

The results based on the decomposition equation (3) are presented in Tables 3 through 11. Table 3 shows that Asian male migrants in Wave 1 have a probability of unemployment that is 16.6 percentage points higher than their non-Asian counterparts. A large part (10.7 percentage points) of this gap is explained in terms of differences in their human capital and other demographic characteristics, and the rest (5.9 percentage points) is due to discrimination (unexplained by differences in their observed characteristics).

From Wave 1 to Wave 3, the probability of unemployment declines for both groups, but the decline is more pronounced for Asians. This narrows down the unemployment gap between the two groups to 13.5 percentage points in Wave 2 and 7.8 percentage points in Wave 3. Only a small proportion of each gap is explained by the differences in their characteristics, the rest is due to discrimination.

The gap in unemployment probabilities between Asian and non-Asian females is 15.9 percentage points in Wave 1 which narrows down to 5.26 and 4.19 percentage points respectively in Waves 2 and 3 . The decomposition analysis reveals very low discrimination (2.66 percentage points) against Asian females in Wave 1. As noted before, there is no evidence of discrimination against them in Waves 2 and 3.

Several factors might be responsible for the existence of discrimination against Asian migrants. First, employers may not have acquired full information about the skills of Asian migrants. Second, employers may not have recognised educational qualifications acquired by Asian migrants from their source country (see Chapman and Iredale, 1993). Third, employees may feel less comfortable in working with Asian migrants and thus employers might have offered jobs to non-Asian migrants even if the Asian migrants could have done the job with the same efficiency. Lastly, the employers may feel that their customers would prefer to deal with non-Asian employees.

Some additional explanation is required to elucidate the phenomenon of low or no discrimination against Asian females. The relatively low discrimination against Asian females as observed in Wave 1 could be because of one or more of the following reasons: First, women are more likely to drop out of the labour force if they are unable to find work (remembering that we are conditioning our probabilities on being in the labour force). Second, to avoid financial hardship, most Asian females might have accepted jobs below their previous occupational status, which they might have refused in the country of their origin. Third, Asian females might have spent more time searching for employment than Asian males to get the jobs. Fourth, Asian females might have presented themselves to the potential employers better than Asian males. Fifth, employers may feel more comfortable in working with Asian females than with Asian males. The absence of discrimination 
against Asian females in Wave 2 and Wave 3 could be due to their faster adaptability in the new environment. Or, it could be due to selectivity bias in the sense that Asian females who could not get jobs after six months of arrival might not have responded to the interview call (out of despair) and thus might not be in our sample for Wave 2 and Wave 3.

All Asian migrants in each gnder group may not be subjected to the same degree of discrimination. That is, there may be very little or no discrimination against one sub-group of Asian migrants, whereas it may be high against another sub-group. It is equally possible that there may be some sub-groups of Asian migrants, which might have been favoured against their non-Asian counterparts. Hence, a decomposition analysis at the disaggregated level is expected to be very informative and useful for policy purposes. In what follows, we present decomposition results for sub-groups of migrants based on age, education, English speaking ability and Visa category in Tables 4 through 11 . Some of the interesting points that emerge from these tables may be briefly stated as follows.

The expected unemployment probability for Asian male migrants is significantly higher than non-Asian migrants in each age group (Table 4). The gap in their unemployment probabilities narrows down as we move from Wave 1 to Wave 3. But the extent of discrimination does wt seem to vary significantly across age groups. There are also significant differences in unemployment probabilities across age groups of females in Wave 1; discrimination is revealed only against middle-aged Asian females (Table 5).

The decomposition results by education groups presented in Table 6 reveal the highest gap (20.52 percentage points) in unemployment probabilities between male Asian degree holders and male non-Asian degree holder in Wave 1. Only 8.88 percentage points of this gap are explained by differences in their characteristics, the remaining gap arising due to discrimination. There is apparently no discrimination against Asian male migrants in other educational categories. On the other hand, Asian female degree holders face very low levels of discrimination. The gap in the probability of unemployment between Asian and non-Asian female migrants in technical/professional education category is 7.71 percentage points. The difference in their characteristics could have widened the gap up to 16.27 percentage points. Hence the negative unexplained differences $(-8.56)$, which is statistically significant, indicates (surprisingly) the existence of discrimination in favour of Asian females. In Waves 2 and 3, the degree of discrimination is the highest against Asian male migrants with high school or less education.

Asian male migrants who speak English "best or only" face the probability of unemployment, which is 21.01 percentage points higher than their non-Asian counterparts in Wave 1. Only 5.24 percentage points of this gap are explained by differences in their characteristics, the rest 15.77 percentage points are due to discrimination. This discrimination disappears in Wave 2. Asian males, who cannot speak English at all, face high levels of discrimination in Waves 1 and 2.

In Wave 1 Asian females who speak English 'best or only' or 'very well' face the highest levels of discrimination, whereas those who cannot speak English at all or 'well' face no discrimination. Asian females who speak English 'well' have the probability of unemployment, which is 13.57 percentage points lower than their non-Asian counterparts. Since the unexplained differences is negative $(-0.1225)$ and statistically significant, it can 
be inferred that Asian females who speak English 'well' get favourable treatment relative to their non-Asian counterparts.

The probability of unemployment for both Asian and non-Asian migrants varies across visa categories. Migrants, who entered Australia in the Business visa category, face low probability of unemployment whereas those, who entered as Refugees, face the highest probability of unemployment. Asian males in Business visa category face low discrimination whereas those in Refugee category face high discrimination (particularly in Waves 2 and 3). Asian males in Independent visa category face relatively low discrimination compared to those who enter under concessional family visa class. Asian females entering into Australia under Business, Preferential or Concessional visas apparently face no discrimination.

Our estimated probit functions support the view that there are significant differences between Asian and non-Asian migrants' probability of getting a job after controlling for demographic variables, English language ability, and the visa category of the migrant. These "unexplained differences" could be due to various problems of measurement or due to exclusion of some explanatory variables. However, we suggest that Asian migrants generally do worse than non-Asian migrants probably due to discrimination in the Australian labour market. Since our sample is restricted to the Principal Applicants, the migrants have been selected by using the same points system for acquiring their visas. As such there is no reason to believe that there are significant differences in the quality/productivity of Asians compared to non-Asians (after controlling for the above mentioned variables). Similarly, since we control for English language ability we are not confounding these effects with discrimination.

We argued that since all the migrants arrived in Australia (roughly) at the same time we do not have some of the problems that were raised in the early literature about cohort effects, nor about where the educational qualifications were acquired ${ }^{14}$. Similarly, since we have controlled for the visa category of the migrants we have allowed for distinct differences between migrants in terms of their ability to find work.

However, although we believe there is discrimination against Asian migrants, the extent of discrimination could be biased if we have excluded an important explanatory variable, see Altonji and Blank (1999). In particular, it is possible that there are differences in qualities of migrants (e.g. motivation, tastes) that may lead us to find significant differences between the two groups. It is, of course, possible that the differences in probabilities between Asian and non-Asians are due to differences in the quality of the educational qualifications. However, in general we found that education was not a significant variable. Alternatively, employers are not valuing Asian qualifications as highly as non-Asian qualifications, see Chapman and Iredale (1993). Finally, the differences between Asian and non-Asian migrants may not be due to discrimination but due to non-Asians having access to better social networks which help them in the labour market. All these qualifications must be kept in mind in evaluating our general findings.

\section{Conclusions and suggestions for future research}

\footnotetext{
${ }^{14}$ It is still possible that employers would prefer migrants with qualifications from the UK than from Vietnam. Since the educational qualifications may have been acquired in Australia, we re-estimated the models using an interactive dummy for Australian qualifications. The results were substantially unchanged.
} 
The main aim of this paper was to investigate if there were differences in the labour market success between Asian and non-Asian migrants which we could ascribe to discrimination, that is differences that could not be explained by variables like human capital, English language ability, demographic variables, etc. Using the LSIA we estimated probit equations for the probability of unemployment. We found significant differences between Asian and non-Asian migrants that could not be explained by usual explanatory variables. These significant differences were mainly for male migrants, while for female migrants we only found significant differences in the first year of their stay in Australia. We argue that these differences are probably due to discrimination against Asian migrants. Further research would look at differences in the earnings of Asian migrants compared to non-Asian migrants. In our analysis we have not explicitly allowed for sample attrition problems nor have we pooled the data set using a balanced sample or used unbalanced samples with appropriate estimation techniques. These are further avenues to explore.

Most of the earlier research in Australia has focussed on earnings functions where researchers have found significant differences between English speaking background (ESB) migrants and non-English speaking background (NESB) migrants where these differences are usually ascribed to poor English language ability. However, in comparison to earlier research we have investigated the issue of discrimination against Asian migrants controlling for English language ability. This research needs to be extended by allowing for possible discrimination against Hispanics as well as against Asians. The number of migrants in Australia from black Africa is too small to carry out any sensible comparisons.

To summarise, we have found prima facie evidence for discrimination against male Asian migrants which policy should address in the future. This discrimination may be because of employers not willing to adequately recognise qualifications of Asian migrants or due to pure discrimination. 


\section{References}

Altonji, J.G. and R. Blank (1999) "Race and Gender in the Labor Market", in O.C. Ashenfelter and D. Card (eds.), Handbook of Labor Economics, Vol. 3A, North-Holland, Elsevier, Amsterdam.

Arrow, K. (1973) "The Theory of Discrimination", in Orley Ashenfelter and Albert Rees (Eds.) Discrimination in Labor Markets, Princeton University Press, Princeton.

Arrow, K. (1998) "What has Economics to say about Racial Discrimination", in Journal of Economic Perspectives, 12 (2), 91-100.

Australia Bureau of Statistics (1996), Labour Force Australia, ABS Cat. No. 6206.0, Canberra.

Baltagi, B.H. (1995) Econometric Analysis of Panel Data, John Wiley and Sons, Chichester.

Becker, G.S. (1957) The Economics of Discrimination, Chicago University Press, Chicago.

Beggs, J.J. and B.J. Chapman (1990) "Search efficiency, Skill Transferability and Immigrant Relative Unemployment Rates in Australia", Applied Economics, 22 (2), 249-260.

Blackaby, D.H., D.G. Leslie, P.D. Murphy and N.C. O’Leary (2002) "White/ethnic minority earnings and employment differentials in Britain: evidence from the LFS", Oxford Economic Papers, 54, 270-297.

Blau, F. and L. Kahn (2000) "Gender Differences in Pay", Journal of Economic Perspectives, 14 (4), 75-99.

Borjas, G.J. (1994) "The Economics of Immigration", Journal of Economic Literature, 32 (4), 1667-1717.

Borjas, G.J. (1999) "The Economic Analysis of Immigration", Chapter 28 in Handbook of Labor Economics Vol. 3A, edited by O.C. Ashenfelter and D. Card, North-Holland, Elsevier, Amsterdam.

Borooah, V.K. and J. Mangan (2002) "An Analysis of Occupational Outcomes for Indigenous and Asian Employees in Australia", Economic Record, 78 (240), 31-49.

Chapman and Miller (1985), “An Appraisal of Immigrants' Labour Market Performance in Australia" in M. E. Poole, P. R. de Lacey and B. S. (eds.), Australia in Transition: Culture and Life Possibilities, Harcourt Brace Jovanovich, Sydney. Randhawa 
Chapman, B. and A. Salvage (1994) "Immigrant Male Wages in Australia: The Role of Education", Centre for Economic Policy Research, Discussion Paper No. 304, Australian National University, Canberra.

Chapman, B. and R.R. Iredale (1993) "Immigrant Qualifications: Recognition and Relative Wage Outcomes", International Migration Review, 27 (2), 359-387.

Chiswick, B. (1983) "An Analysis of the Earnings and Employment of AsianAmerican Men", Journal of Labor Economics, 1 (2), 897-921.

Cobb-Clark, D.A. (2000) "Do Selection Criteria Make a Difference? Visa Category and the Labour Market Status of Immigrants to Australia", Economic Record, 76 (232), 15-31.

Cobb-Clark, D.A. and B. Chapman (1999) "The Changing Pattern of Immigrants' Labour Market Experiences", Centre for Economic Policy Research Discussion Paper No. 396, Australian National University, Canberra.

Darity, W.A. and P.J. Mason (1998) "Evidence on Discrimination in Employment", Journal of Economic Perspectives, 12 (2), 63-90.

Department of Immigration and Multicultural Affairs (1999) Longitudinal Survey of Immigrants to Australia, User Documentation for August 1999 Release of Unit Record Data, Waves 1-3, Canberra.

Doiron, D, and W.C. Riddell (1994) "The Impact of Unionization on Male-Female Earnings Differences in Canada", Journal of Human Resources, 29 (2), 504534.

Evans, M.D.R. and J. Kelley (1986) "Immigrants' Work: Equality and Discrimination in the Australian Labour Market", Australia New Zealand Journal of Sociology, 22 (2), 187-207.

Foster, L., A. Marshall and L. S. Williams (1991), Discrimination Again Immigrant Workers in Australia, AGPS, Canberra.

Greene, W. H. (1990), Econometric Analysis, Macmillan, New York

Heckman, J.J. (1998) "Detecting Discrimination", Journal of Economic Perspectives, $12(2), 101-116$.

Hum, D. and W. Simpson (1999) "Wage Opportunities for Visible Minorities in Canada, Canadian Public Policy, 25, 379-394.

Hum, D. and W. Simpson (2000) "Closing the Wage Gap: Economic Assimilation of Canadian Immigrants Reconsidered", Journal of International Migration and Integration, 1 (4), 427-441.

Inglis, P. A. and T. Stromback (1984), “A Descriptive Analysis of Migrants' Labour Market Experience", Bureau of Labour market research, Working Paper No. 38, March. 
Kidd, M. P. and Xin Meng (1997) "Trends in the Australian Gender Wage Differential over the 1980s: Some Evidence on the Effectiveness of Legislative Reform" Australian Economic Review; 30(1), 31-44.

LaLonde, R. J. and R.H. Topel (1991) "Immigrants in the American Labor Market: Quality, Assimilation, and Distributional Effects", American Economic Review, 81 (2), 297-302.

Le, A. T. and P. W. Miller (2000), "Australia's Unemployment Problem", The Economic Record, March, Vol. 76, No. 232, 74-104.

Miller, P. W. (1982), “ The Economic Position of Migrants: Facts and FallaciesA Preliminary View", A ustralian Bulletin of Labour, Vol. 8, September, 229-48.

Miller, P. W. (1986) "Immigrant Unemployment in the First Year of Australian Labour Market Activity", Economic Record, Vol. 62, March, 82-87.

Oaxaca, R and M. R. Ransom (1994), " On Discrimination and the Decomposition of Wage Differentials", Journal of Econometrics, 61, 5-21.

Oaxaca, R. (1973) "Male-Female Wage Differentials in Urban Labour Markets", International Economic Review, 14(3), 693-709.

Phelps, E.S. (1972) "The Statistical theory of racism and sexism", American Economic Review, 62(4), 659-61.

Silber, J. and M. Weber (1999), "Labour Market Discrimination: Are there Significant Differences between the Various Decomposition Procedures?", Applied Economics, 31(3), March, 359-365.

VandenHeuevel, A. and M. Wooden (2000) 'Immigrants' Labour Market Experiences in the Early Settlement Years", Australian Bulletin of Labour, 26 (1), 59-69.

Will, L.M. (1997) Australian Non-English Speaking Background Immigrants' Income Adjustment, Ph.D. thesis submitted to the Australian National University, Canberra (unpublished).

Williams, L. S., J. Murphy and C. Brooks (1997) Initial Labour Market Experiences of Immigrants, Results from the Longitudinal Survey of Immigrants to Australia, Department of Immigration and Multicultural Affairs, AGPS, Canberra.

Wooden, M. (1991) "The Experience of Refugees in the Australian Labour Market", International Migration Review, 25 (3), 514-535.

Wooden, M. (1994) "The labour market experience of immigrants", in Australian Immigration: A Survey of the Issues by M. Wooden, R. Holton, G. Hugo, and J. Sloan, Canberra: AGPS. 
Wooden, M. and F. Robertson (1989), The Factors Associated with M igrant Labour Market Status, Report commissioned by the Bureau of Immigration Research, Canberra.

Wooden, M., R. Holton, G. Hugo, and J. Sloan (eds) (1994), “The Labour Market Experience of Immigrants", A ustralian Immigration: A Survey of the Issues, AGPS, Canberra. 


\section{Appendix 1: Variable Definitions}

Dependent variable:

Unemployed $=1$ if Unemployed

$=0$ otherwise

Note: Default category is within parentheses.

Demographic Variable

Age $=$ age of migrant (measured in years)

Married $=1$ if migrant is married or previously married

$=0$ otherwise

Visited Australia $=1$ if migrant visited Australia before migration $=0$ otherwise

Asian $=1$ if migrant is Asian

$=0$ otherwise

Note: Asians are the migrants who were born in an Asian country and in any country of the Middle East or North Africa (See text for details).

English [Not at all]

Only or Best $=1$ if migrant speaks English Only or Best $=0$ otherwise

Very Well $=1$ if migrant speaks English Very Well $=0$ otherwise

Well $=1$ if migrant speaks English Well

$=0$ otherwise

Poor $=1$ if migrant speaks Poor English $=0$ otherwise

Education [High School or less]

Graduate $=1$ if migrant has Degree or Higher Education $=0$ otherwise

Technical $/$ Trade $=1$ if migrant has Technical/Professional Qualification (diploma/certificate) $=0$ otherwise

\section{Visa Category [ Business Skills/ENT]}

Preferential Family $=1$ if migrated under Preferential Family Category $=0$ otherwise

Concessional Family $=1$ if migrated under Concessional Family Category $=0$ otherwise 
Independent $=1$ if migrated under Independent Category $=0$ otherwise

Refugee $=1$ if migrated under Humanitarian (Refugee) Category $=0$ otherwise

\section{State of Residence [New South Wales (NSW)]}

Victoria $=1$ if migrant interviewed in or lives in Victoria $=0$ otherwise

$\mathrm{QLD}=1$ if migrant interviewed in or lives in Queensland $=0$ otherwise

$\mathrm{SA}=1$ if migrant interviewed in or lives in South Australia $=0$ otherwise

$\mathrm{WA}=1$ if migrant interviewed in or lives in Western Australia $=0$ otherwise

$\mathrm{NT}=1$ if migrant interviewed in or lives in Northern Territory $=0$ otherwise

ACT $=1$ if migrant interviewed in or lives in Australian National Territory $=0$ otherwise

Tasmania $=1$ if migrant interviewed in or lives in Tasmania $=0$ otherwise. 
Table 3

Decomposition of Unemployment Probability Gap between Asian and Non-Asian Migrants

\begin{tabular}{|c|c|c|c|c|c|}
\hline \multirow[t]{2}{*}{ Waves } & \multirow{2}{*}{$\begin{array}{l}\text { Average } \\
\text { Unemployment } \\
\text { Probability for } \\
\text { Asian Immigrants }\end{array}$} & \multirow{2}{*}{$\begin{array}{l}\text { Average } \\
\text { Unemployment } \\
\text { Probability for Non } \\
\text { Asian Immigrants } \\
\end{array}$} & \multirow{2}{*}{$\begin{array}{l}\text { Unemployment } \\
\text { Probability Gap }\end{array}$} & \multicolumn{2}{|c|}{ Decomposition of Gap } \\
\hline & & & & $\begin{array}{l}\text { Explained } \\
\text { Differences }\end{array}$ & $\begin{array}{l}\text { Unexplained } \\
\text { Differences }\end{array}$ \\
\hline \multicolumn{6}{|c|}{ Males } \\
\hline Wave 1 & $\begin{array}{l}45.30 \\
(0.81)\end{array}$ & $\begin{array}{l}28.69 \\
(0.78)\end{array}$ & $\begin{array}{l}16.61 \\
(1.12)\end{array}$ & $\begin{array}{c}10.73 \\
(1.09)\end{array}$ & $\begin{array}{c}5.88 \\
(1.11)\end{array}$ \\
\hline Wave 2 & $\begin{array}{l}28.40 \\
(0.70)\end{array}$ & $\begin{array}{l}14.90 \\
(0.48) \\
\end{array}$ & $\begin{array}{l}13.50 \\
(0.85)\end{array}$ & $\begin{array}{l}3.49 \\
(0.67) \\
\end{array}$ & $\begin{array}{l}10.01 \\
(0.84) \\
\end{array}$ \\
\hline Wave 3 & $\begin{array}{l}17.00 \\
(0.51) \\
\end{array}$ & $\begin{array}{l}9.20 \\
(0.42) \\
\end{array}$ & $\begin{array}{l}7.80 \\
(0.66) \\
\end{array}$ & $\begin{array}{l}2.41 \\
(0.61)\end{array}$ & $\begin{array}{l}5.39 \\
(0.67)\end{array}$ \\
\hline \multicolumn{6}{|c|}{ Females } \\
\hline Wave 1 & $\begin{array}{l}47.54 \\
(1.09)\end{array}$ & $\begin{array}{l}31.64 \\
(1.13)\end{array}$ & $\begin{array}{l}15.90 \\
(1.57)\end{array}$ & $\begin{array}{l}13.24 \\
(1.55)\end{array}$ & $\begin{array}{l}2.66 \\
(1.53)\end{array}$ \\
\hline Wave 2 & $\begin{array}{l}24.52 \\
(0.94)\end{array}$ & $\begin{array}{l}19.26 \\
(0.96)\end{array}$ & $\begin{array}{l}5.26 \\
(1.34)\end{array}$ & $\begin{array}{l}5.26 \\
(1.34)\end{array}$ & - \\
\hline Wave 3 & $\begin{array}{l}18.26 \\
(0.78)\end{array}$ & $\begin{array}{l}14.07 \\
(0.87)\end{array}$ & $\begin{array}{l}4.19 \\
(1.13)\end{array}$ & $\begin{array}{l}4.19 \\
(1.13)\end{array}$ & - \\
\hline
\end{tabular}

Note: Parentheses contain standard errors. 
Table 4

Decomposition of Unemployment Probability Gap between Asian and Non Asian Male Migrants by Age Group

(Young: Age $\leq 30$; Middle Age: $30<$ Age $\leq 45$; Old: Age $>45$ )

\begin{tabular}{|c|c|c|c|c|c|}
\hline \multirow[t]{2}{*}{ Age Group } & \multirow{2}{*}{$\begin{array}{l}\text { Average } \\
\text { Unemployment } \\
\text { Probability for } \\
\text { Asian Immigrants }\end{array}$} & \multirow[b]{2}{*}{$\begin{array}{l}\text { Average } \\
\text { Unemployment } \\
\text { Probability for } \\
\text { Non Asian } \\
\text { Immigrants } \\
\end{array}$} & \multirow{2}{*}{$\begin{array}{l}\text { Unemployment } \\
\text { Probability Gap }\end{array}$} & \multicolumn{2}{|c|}{ Decomposition of Gap } \\
\hline & & & & $\begin{array}{l}\text { Explained } \\
\text { Differences }\end{array}$ & $\begin{array}{l}\text { Unexplained } \\
\text { Differences }\end{array}$ \\
\hline \multicolumn{6}{|c|}{ Wave 1} \\
\hline Young & $\begin{array}{l}44.48 \\
(1.11)\end{array}$ & $\begin{array}{r}28.31 \\
(1.07)\end{array}$ & $\begin{array}{r}16.17 \\
(1.54)\end{array}$ & $\begin{array}{l}9.85 \\
(1.50)\end{array}$ & $\begin{array}{c}6.32 \\
(1.53)\end{array}$ \\
\hline Middle Age & $\begin{array}{l}44.76 \\
(1.14)\end{array}$ & $\begin{array}{r}26.62 \\
(1.11)\end{array}$ & $\begin{array}{c}18.14 \\
(1.59)\end{array}$ & $\begin{array}{r}12.78 \\
(1.54)\end{array}$ & $\begin{array}{l}5.36 \\
(1.56)\end{array}$ \\
\hline$\overline{\text { Old }}$ & $\begin{array}{r}51.05 \\
(3.42)\end{array}$ & $\begin{array}{l}39.96 \\
(3.18)\end{array}$ & $\begin{array}{r}11.09 \\
(4.67)\end{array}$ & $\begin{array}{c}5.97 \\
(4.62)\end{array}$ & $\begin{array}{c}5.12 \\
(4.79)\end{array}$ \\
\hline \multicolumn{6}{|c|}{ Wave 2} \\
\hline Young & $\begin{array}{l}26.91 \\
(1.02)\end{array}$ & $\begin{array}{l}12.48 \\
(0.58)\end{array}$ & $\begin{array}{l}14.43 \\
(1.17)\end{array}$ & $\begin{array}{l}3.23 \\
(0.81)\end{array}$ & $\begin{array}{l}11.20 \\
(1.17)\end{array}$ \\
\hline Middle Age & $\begin{array}{l}27.39 \\
(0.93)\end{array}$ & $\begin{array}{l}14.26 \\
(0.61)\end{array}$ & $\begin{array}{l}13.13 \\
(1.45)\end{array}$ & $\begin{array}{l}4.45 \\
(0.88)\end{array}$ & $\begin{array}{l}8.68 \\
(1.13)\end{array}$ \\
\hline Old & $\begin{array}{l}37.99 \\
(2.79)\end{array}$ & $\begin{array}{l}23.97 \\
(2.11) \\
\end{array}$ & $\begin{array}{l}14.02 \\
(3.50) \\
\end{array}$ & $\begin{array}{l}1.07 \\
(3.03)\end{array}$ & $\begin{array}{l}12.95 \\
(3.53) \\
\end{array}$ \\
\hline \multicolumn{6}{|c|}{ Wave 3} \\
\hline Young & $\begin{array}{l}15.20 \\
(0.84) \\
\end{array}$ & $\begin{array}{l}8.21 \\
(0.78) \\
\end{array}$ & $\begin{array}{l}6.99 \\
(1.15) \\
\end{array}$ & $\begin{array}{l}1.48 \\
(1.08) \\
\end{array}$ & $\begin{array}{l}5.51 \\
(1.13) \\
\end{array}$ \\
\hline Middle Age & $\begin{array}{l}15.58 \\
(0.58)\end{array}$ & $\begin{array}{l}7.76 \\
(0.44)\end{array}$ & $\begin{array}{l}7.82 \\
(0.73)\end{array}$ & $\begin{array}{l}2.53 \\
(0.67)\end{array}$ & $\begin{array}{l}5.29 \\
(0.77)\end{array}$ \\
\hline Old & $\begin{array}{l}27.29 \\
(1.94)\end{array}$ & $\begin{array}{l}16.53 \\
(1.57) \\
\end{array}$ & $\begin{array}{l}10.76 \\
(2.50) \\
\end{array}$ & $\begin{array}{l}5.06 \\
(2.36) \\
\end{array}$ & $\begin{array}{l}5.70 \\
(2.62) \\
\end{array}$ \\
\hline
\end{tabular}

Note: Parentheses contain standard errors. 
Table 5

Decomposition of Unemployment Probability Gap between Asian and Non Asian Female Migrants

by Age Group

(Young: Age $\leq 30$, Middle Age: $30<$ Age $\leq 45$ and Old: Age $>45$ )

\begin{tabular}{|c|c|c|c|c|c|}
\hline \multirow[t]{2}{*}{ Age Group } & \multirow{2}{*}{$\begin{array}{l}\text { Average } \\
\text { Unemployment } \\
\text { Probability for } \\
\text { Asian Immigrants }\end{array}$} & \multirow{2}{*}{$\begin{array}{l}\text { Average } \\
\text { Unemployment } \\
\text { Probability for Non } \\
\text { Asian Immigrants }\end{array}$} & \multirow{2}{*}{$\begin{array}{l}\text { Unemployment } \\
\text { Probability Gap }\end{array}$} & \multicolumn{2}{|c|}{ Decomposition of Gap } \\
\hline & & & & $\begin{array}{l}\text { Explained } \\
\text { Differences }\end{array}$ & $\begin{array}{l}\text { Unexplained } \\
\text { Differences }\end{array}$ \\
\hline \multicolumn{6}{|c|}{ Wave 1} \\
\hline Young & $\begin{array}{l}45.00 \\
(1.49)\end{array}$ & $\begin{array}{l}30.76 \\
(1.63)\end{array}$ & $\begin{array}{l}14.24 \\
(2.21)\end{array}$ & $\begin{array}{l}14.81 \\
(2.28)\end{array}$ & $\begin{array}{l}-0.57 \\
(2.18)\end{array}$ \\
\hline Middle Age & $\begin{array}{l}49.36 \\
(1.79)\end{array}$ & $\begin{array}{l}31.42 \\
(1.88)\end{array}$ & $\begin{array}{l}17.94 \\
(2.60)\end{array}$ & $\begin{array}{l}13.09 \\
(2.57)\end{array}$ & $\begin{array}{l}4.85 \\
(2.50)\end{array}$ \\
\hline Old & $\begin{array}{l}65.71 \\
(6.66)\end{array}$ & $\begin{array}{l}44.75 \\
(5.23)\end{array}$ & $\begin{array}{l}20.96 \\
(8.47)\end{array}$ & $\begin{array}{l}14.96 \\
(8.25)\end{array}$ & $\begin{array}{l}6.00 \\
(9.22)\end{array}$ \\
\hline \multicolumn{6}{|c|}{ Wave 2} \\
\hline Young & $\begin{array}{l}25.48 \\
(1.37)\end{array}$ & $\begin{array}{l}16.23 \\
(1.19)\end{array}$ & $\begin{array}{l}9.25 \\
(1.81)\end{array}$ & $\begin{array}{l}9.25 \\
(1.81)\end{array}$ & - \\
\hline Middle Age & $\begin{array}{l}22.31 \\
(1.31)\end{array}$ & $\begin{array}{l}19.22 \\
(1.44)\end{array}$ & $\begin{array}{l}3.09 \\
(1.95)\end{array}$ & $\begin{array}{l}3.09 \\
(1.95)\end{array}$ & - \\
\hline Old & $\begin{array}{l}35.45 \\
(4.54)\end{array}$ & $\begin{array}{l}36.45 \\
(4.03)\end{array}$ & $\begin{array}{l}-1.00 \\
(6.07)\end{array}$ & $\begin{array}{l}-1.00 \\
(6.07)\end{array}$ & - \\
\hline \multicolumn{6}{|c|}{ Wave 3} \\
\hline Young & $\begin{array}{l}19.57 \\
(1.22)\end{array}$ & $\begin{array}{l}13.87 \\
(1.32)\end{array}$ & $\begin{array}{l}5.70 \\
(1.80)\end{array}$ & $\begin{array}{l}5.70 \\
(1.80)\end{array}$ & - \\
\hline Middle Age & $\begin{array}{l}16.29 \\
(0.98)\end{array}$ & $\begin{array}{l}12.44 \\
(1.08)\end{array}$ & $\begin{array}{l}3.85 \\
(1.46)\end{array}$ & $\begin{array}{l}3.85 \\
(1.46)\end{array}$ & - \\
\hline Old & $\begin{array}{l}27.16 \\
(3.94)\end{array}$ & $\begin{array}{l}21.96 \\
(2.63)\end{array}$ & $\begin{array}{l}5.20 \\
(4.74)\end{array}$ & $\begin{array}{l}5.20 \\
(4.74)\end{array}$ & - \\
\hline
\end{tabular}

Note: Parentheses contain standard errors. 
Table 6

Decomposition of Unemployment Probability Gap between Asian and Non Asian Male Migrants by Levels of Education

\begin{tabular}{|c|c|c|c|c|c|}
\hline \multirow{2}{*}{$\begin{array}{l}\text { Level of } \\
\text { Education }\end{array}$} & \multirow{2}{*}{$\begin{array}{l}\text { Average } \\
\text { Unemployment } \\
\text { Probability for } \\
\text { Asian Immigrants }\end{array}$} & \multirow{2}{*}{$\begin{array}{l}\text { Average } \\
\text { Unemployment } \\
\text { Probability for Non } \\
\text { Asian Immigrants }\end{array}$} & \multirow{2}{*}{$\begin{array}{l}\text { Unemployment } \\
\text { Probability Gap }\end{array}$} & \multicolumn{2}{|c|}{ Decomposition of Gap } \\
\hline & & & & $\begin{array}{l}\text { Explained } \\
\text { Differences }\end{array}$ & $\begin{array}{l}\text { Unexplained } \\
\text { Differences }\end{array}$ \\
\hline \multicolumn{6}{|c|}{$\begin{array}{ll}\text { Wave } 1 \\
\end{array}$} \\
\hline Degree & $\begin{array}{l}44.23 \\
(1.06)\end{array}$ & $\begin{array}{l}23.71 \\
(1.21)\end{array}$ & $\begin{array}{l}20.52 \\
(1.61)\end{array}$ & $\begin{array}{l}8.88 \\
(1.54)\end{array}$ & $\begin{array}{l}11.64 \\
(1.42)\end{array}$ \\
\hline $\begin{array}{l}\text { Technical// } \\
\text { Professional }\end{array}$ & $\begin{array}{l}35.06 \\
(1.33)\end{array}$ & $\begin{array}{l}26.65 \\
(1.12)\end{array}$ & $\begin{array}{l}8.41 \\
(1.74)\end{array}$ & $\begin{array}{l}8.97 \\
(2.19)\end{array}$ & $\begin{array}{l}-0.56 \\
(1.88)\end{array}$ \\
\hline Other & $\begin{array}{l}55.71 \\
(1.72)\end{array}$ & $\begin{array}{l}42.93 \\
(1.76)\end{array}$ & $\begin{array}{l}12.78 \\
(2.46)\end{array}$ & $\begin{array}{l}10.83 \\
(2.36)\end{array}$ & $\begin{array}{l}1.95 \\
(2.33)\end{array}$ \\
\hline \multicolumn{6}{|c|}{ Wave 2} \\
\hline Degree & $\begin{array}{l}23.40 \\
(0.88)\end{array}$ & $\begin{array}{l}13.34 \\
(0.78)\end{array}$ & $\begin{array}{l}10.06 \\
(1.18)\end{array}$ & $\begin{array}{l}1.93 \\
(0.99)\end{array}$ & $\begin{array}{l}8.13 \\
(1.08)\end{array}$ \\
\hline $\begin{array}{l}\text { Technical/ } \\
\text { Professional }\end{array}$ & $\begin{array}{l}21.15 \\
(1.12)\end{array}$ & $\begin{array}{l}15.14 \\
(0.73)\end{array}$ & $\begin{array}{l}6.01 \\
(1.34)\end{array}$ & $\begin{array}{l}2.33 \\
(1.13)\end{array}$ & $\begin{array}{l}3.68 \\
(1.41)\end{array}$ \\
\hline Other & $\begin{array}{l}42.35 \\
(1.39)\end{array}$ & $\begin{array}{l}17.78 \\
(1.07)\end{array}$ & $\begin{array}{l}24.57 \\
(1.75)\end{array}$ & $\begin{array}{l}6.25 \\
(1.46)\end{array}$ & $\begin{array}{l}18.32 \\
(1.71)\end{array}$ \\
\hline \multicolumn{6}{|c|}{ Wave 3} \\
\hline Degree & $\begin{array}{l}13.78 \\
(0.62)\end{array}$ & $\begin{array}{l}6.97 \\
(0.56)\end{array}$ & $\begin{array}{l}6.81 \\
(0.84)\end{array}$ & $\begin{array}{l}0.25 \\
(0.69)\end{array}$ & $\begin{array}{l}6.56 \\
(0.74)\end{array}$ \\
\hline $\begin{array}{l}\text { Technical/ } \\
\text { Professional }\end{array}$ & $\begin{array}{l}12.96 \\
(0.82)\end{array}$ & $\begin{array}{l}8.73 \\
(0.63)\end{array}$ & $\begin{array}{l}4.23 \\
(1.03)\end{array}$ & $\begin{array}{l}2.17 \\
(1.02)\end{array}$ & $\begin{array}{l}2.06 \\
(1.15)\end{array}$ \\
\hline Other & $\begin{array}{l}26.11 \\
(1.08)\end{array}$ & $\begin{array}{l}14.96 \\
(1.15)\end{array}$ & $\begin{array}{l}11.15 \\
(1.58)\end{array}$ & $\begin{array}{l}4.38 \\
(1.56)\end{array}$ & $\begin{array}{l}6.77 \\
(1.51)\end{array}$ \\
\hline
\end{tabular}

Note: Parentheses contain standard errors. 
Table 7

Decomposition of Unemployment Probability Gap between Asian and Non Asian Female Migrants by Levels of Education

\begin{tabular}{|c|c|c|c|c|c|}
\hline \multirow{2}{*}{$\begin{array}{l}\text { Levels of } \\
\text { Education }\end{array}$} & \multirow{2}{*}{$\begin{array}{l}\text { Average } \\
\text { Unemployment } \\
\text { Probability for } \\
\text { Asian Immigrants }\end{array}$} & \multirow{2}{*}{$\begin{array}{l}\text { Average } \\
\text { Unemployment } \\
\text { Probability for Non } \\
\text { Asian Immigrants }\end{array}$} & \multirow{2}{*}{$\begin{array}{l}\text { Unemployment } \\
\text { Probability } \\
\text { Gap }\end{array}$} & \multicolumn{2}{|c|}{ Decomposition of Gap } \\
\hline & & & & $\begin{array}{l}\text { Explained } \\
\text { Differences }\end{array}$ & $\begin{array}{l}\text { Unexplained } \\
\text { Differences }\end{array}$ \\
\hline \multicolumn{6}{|c|}{$\begin{array}{ll}\text { Wave } 1 \\
\end{array}$} \\
\hline Degree & $\begin{array}{l}44.58 \\
(1.41)\end{array}$ & $\begin{array}{l}27.85 \\
(1.56)\end{array}$ & $\begin{array}{l}16.73 \\
(2.10)\end{array}$ & $\begin{array}{l}11.05 \\
(2.12)\end{array}$ & $\begin{array}{l}6.49 \\
(2.01)\end{array}$ \\
\hline $\begin{array}{l}\text { Technical/ } \\
\text { Professional }\end{array}$ & $\begin{array}{l}35.99 \\
(2.26)\end{array}$ & $\begin{array}{l}28.28 \\
(1.82)\end{array}$ & $\begin{array}{l}7.71 \\
(2.90)\end{array}$ & $\begin{array}{l}16.27 \\
(2.90)\end{array}$ & $\begin{array}{l}-8.56 \\
(3.20)\end{array}$ \\
\hline Other & $\begin{array}{l}60.97 \\
(2.27)\end{array}$ & $\begin{array}{l}47.46 \\
(3.25)\end{array}$ & $\begin{array}{l}13.51 \\
(0.16)\end{array}$ & $\begin{array}{l}14.78 \\
(3.89)\end{array}$ & $\begin{array}{l}-1.27 \\
(3.11)\end{array}$ \\
\hline \multicolumn{6}{|c|}{ Wave 2} \\
\hline Degree & $\begin{array}{l}19.64 \\
(1.07)\end{array}$ & $\begin{array}{l}13.67 \\
(1.16)\end{array}$ & $\begin{array}{l}5.97 \\
(1.58)\end{array}$ & $\begin{array}{l}5.97 \\
(1.58)\end{array}$ & - \\
\hline $\begin{array}{l}\text { Technical/ } \\
\text { Professional }\end{array}$ & $\begin{array}{l}14.84 \\
(1.47)\end{array}$ & $\begin{array}{l}14.35 \\
(1.30)\end{array}$ & $\begin{array}{l}0.49 \\
(1.96)\end{array}$ & $\begin{array}{l}0.49 \\
(1.96)\end{array}$ & - \\
\hline Other & $\begin{array}{l}39.93 \\
(1.74)\end{array}$ & $\begin{array}{l}35.31 \\
(2.19)\end{array}$ & $\begin{array}{l}4.62 \\
(2.80)\end{array}$ & $\begin{array}{l}4.62 \\
(2.80)\end{array}$ & - \\
\hline \multicolumn{6}{|c|}{ Wave 3} \\
\hline Degree & $\begin{array}{l}9.05 \\
(0.66) \\
\end{array}$ & $\begin{array}{l}5.16 \\
(0.60) \\
\end{array}$ & $\begin{array}{l}3.89 \\
(0.89) \\
\end{array}$ & $\begin{array}{l}3.89 \\
(0.89) \\
\end{array}$ & - \\
\hline $\begin{array}{l}\text { Technical/ } \\
\text { Professional }\end{array}$ & $\begin{array}{l}17.57 \\
(1.44)\end{array}$ & $\begin{array}{l}14.54 \\
(1.27)\end{array}$ & $\begin{array}{l}2.96 \\
(1.92)\end{array}$ & $\begin{array}{l}2.96 \\
(1.92)\end{array}$ & - \\
\hline Other & $\begin{array}{l}32.09 \\
(1.18)\end{array}$ & $\begin{array}{l}27.77 \\
(1.79)\end{array}$ & $\begin{array}{l}4.32 \\
(2.14)\end{array}$ & $\begin{array}{l}4.32 \\
(2.14)\end{array}$ & - \\
\hline
\end{tabular}

Note: Parentheses contain standard errors. 
Table 8

Decomposition of Unemployment Probability Gap between Asian and Non Asian Male Migrants by English Speaking Ability

\begin{tabular}{|c|c|c|c|c|c|}
\hline \multirow{3}{*}{$\begin{array}{l}\text { English } \\
\text { Speaking } \\
\text { Ability }\end{array}$} & \multirow{3}{*}{$\begin{array}{l}\text { Average } \\
\text { Unemployment } \\
\text { Probability for } \\
\text { Asian Immigrants }\end{array}$} & \multirow{3}{*}{$\begin{array}{l}\text { Average } \\
\text { Unemployment } \\
\text { Probability for } \\
\text { Non Asian } \\
\text { Immigrants }\end{array}$} & \multirow{3}{*}{$\begin{array}{l}\text { Unemployment } \\
\text { Probability } \\
\text { Gap }\end{array}$} & \multicolumn{2}{|c|}{ Decomposition of Gap } \\
\hline & & & & Explained & Unexplained \\
\hline & & & & Differences & Differences \\
\hline \multicolumn{6}{|c|}{ Wave 1} \\
\hline Best/Only & $\begin{array}{l}32.40 \\
(1.41)\end{array}$ & $\begin{array}{l}11.39 \\
(0.48)\end{array}$ & $\begin{array}{l}21.01 \\
(1.49)\end{array}$ & $\begin{array}{l}5.24 \\
(0.97)\end{array}$ & $\begin{array}{l}15.77 \\
(1.64)\end{array}$ \\
\hline Very Well & $\begin{array}{l}38.10 \\
(1.63)\end{array}$ & $\begin{array}{l}28.96 \\
(1.71)\end{array}$ & $\begin{array}{l}9.14 \\
(2.36)\end{array}$ & $\begin{array}{l}4.01 \\
(2.20)\end{array}$ & $\begin{array}{l}5.13 \\
(2.14)\end{array}$ \\
\hline Well & $\begin{array}{l}43.72 \\
(1.29)\end{array}$ & $\begin{array}{l}28.96 \\
(1.71)\end{array}$ & $\begin{array}{l}14.76 \\
(2.14)\end{array}$ & $\begin{array}{l}11.70 \\
(2.06)\end{array}$ & $\begin{array}{l}3.06 \\
(1.72)\end{array}$ \\
\hline Not Well & $\begin{array}{l}52.41 \\
(1.65)\end{array}$ & $\begin{array}{l}57.93 \\
(1.75)\end{array}$ & $\begin{array}{l}-5.52 \\
(2.41)\end{array}$ & $\begin{array}{l}-6.30 \\
(2.35)\end{array}$ & $\begin{array}{l}0.78 \\
(2.28)\end{array}$ \\
\hline Not At All & $\begin{array}{l}77.52 \\
(2.79) \\
\end{array}$ & $\begin{array}{l}62.14 \\
(3.39) \\
\end{array}$ & $\begin{array}{l}15.38 \\
(4.39) \\
\end{array}$ & $\begin{array}{l}-2.63 \\
(4.57) \\
\end{array}$ & $\begin{array}{l}18.01 \\
(4.14) \\
\end{array}$ \\
\hline \multicolumn{6}{|c|}{ Wave 2} \\
\hline Best/Only & $\begin{array}{l}9.00 \\
(0.60)\end{array}$ & $\begin{array}{l}6.15 \\
(0.25)\end{array}$ & $\begin{array}{l}2.85 \\
(0.65)\end{array}$ & $\begin{array}{l}2.60 \\
(0.53)\end{array}$ & $\begin{array}{l}0.25 \\
(0.76)\end{array}$ \\
\hline Very Well & $\begin{array}{l}21.18 \\
(1.04)\end{array}$ & $\begin{array}{l}9.53 \\
(0.82)\end{array}$ & $\begin{array}{l}11.65 \\
(1.32)\end{array}$ & $\begin{array}{l}9.67 \\
(1.00)\end{array}$ & $\begin{array}{l}10.69 \\
(1.19)\end{array}$ \\
\hline Well & $\begin{array}{l}27.18 \\
(0.98)\end{array}$ & $\begin{array}{l}21.95 \\
(0.96)\end{array}$ & $\begin{array}{l}5.23 \\
(1.37)\end{array}$ & $\begin{array}{l}-2.38 \\
(1.19)\end{array}$ & $\begin{array}{l}7.61 \\
(1.21)\end{array}$ \\
\hline Not Well & $\begin{array}{l}44.47 \\
(1.43)\end{array}$ & $\begin{array}{l}33.08 \\
(1.41)\end{array}$ & $\begin{array}{l}11.39 \\
(2.01)\end{array}$ & $\begin{array}{l}5.77 \\
(1.79)\end{array}$ & $\begin{array}{l}17.16 \\
(1.80)\end{array}$ \\
\hline Not At All & $\begin{array}{l}55.07 \\
(4.33)\end{array}$ & $\begin{array}{l}26.30 \\
(5.14)\end{array}$ & $\begin{array}{l}28.77 \\
(6.72) \\
\end{array}$ & $\begin{array}{l}0.96 \\
(6.03)\end{array}$ & $\begin{array}{l}27.81 \\
(5.35)\end{array}$ \\
\hline \multicolumn{6}{|c|}{ Wave 3} \\
\hline Best/Only & $\begin{array}{l}6.59 \\
(0.47)\end{array}$ & $\begin{array}{l}2.13 \\
(0.15)\end{array}$ & $\begin{array}{l}4.46 \\
(0.49)\end{array}$ & $\begin{array}{l}-0.32 \\
(2.14)\end{array}$ & $\begin{array}{l}4.78 \\
(0.50)\end{array}$ \\
\hline Very Well & $\begin{array}{l}9.15 \\
(0.50) \\
\end{array}$ & $\begin{array}{l}10.97 \\
(0.87)\end{array}$ & $\begin{array}{l}-1.82 \\
(1.00)\end{array}$ & $\begin{array}{l}-2.61 \\
(1.01) \\
\end{array}$ & $\begin{array}{l}0.79 \\
(0.71) \\
\end{array}$ \\
\hline Well & $\begin{array}{l}15.13 \\
(0.53)\end{array}$ & $\begin{array}{l}11.04 \\
(0.72)\end{array}$ & $\begin{array}{l}4.09 \\
(0.89)\end{array}$ & $\begin{array}{l}-1.76 \\
(0.85)\end{array}$ & $\begin{array}{l}5.85 \\
(0.70)\end{array}$ \\
\hline Not Well & $\begin{array}{l}34.37 \\
(1.21)\end{array}$ & $\begin{array}{l}28.20 \\
(1.58)\end{array}$ & $\begin{array}{l}6.17 \\
(2.00)\end{array}$ & $\begin{array}{l}-2.61 \\
(2.01)\end{array}$ & $\begin{array}{l}8.78 \\
(1.73)\end{array}$ \\
\hline Not At All & $\begin{array}{l}39.73 \\
(4.43)\end{array}$ & $\begin{array}{l}23.87 \\
(9.75)\end{array}$ & $\begin{array}{l}15.86 \\
(10.71)\end{array}$ & $\begin{array}{l}6.37 \\
(10.68)\end{array}$ & $\begin{array}{l}9.49 \\
(6.22)\end{array}$ \\
\hline
\end{tabular}

Note: Parentheses contain standard errors. 
Table 9

Decomposition of Unemployment Probability Gap between Asian and Non Asian Female Migrants by English Speaking Ability

\begin{tabular}{|c|c|c|c|c|c|}
\hline \multirow{3}{*}{$\begin{array}{l}\text { English } \\
\text { Speaking } \\
\text { Ability }\end{array}$} & \multirow{3}{*}{$\begin{array}{l}\text { Average } \\
\text { Unemployment } \\
\text { Probability for } \\
\text { Asian Immigrants }\end{array}$} & \multirow{3}{*}{$\begin{array}{l}\text { Average } \\
\text { Unemployment } \\
\text { Probability for } \\
\text { Non Asian } \\
\text { Immigrants }\end{array}$} & \multirow{3}{*}{$\begin{array}{l}\text { Unemployment } \\
\text { Probability } \\
\text { Gap }\end{array}$} & \multicolumn{2}{|c|}{ Decomposition of Gap } \\
\hline & & & & Explained & Unexplained \\
\hline & & & & Differences & Differences \\
\hline \multicolumn{6}{|c|}{ Wave 1} \\
\hline Best/Only & $\begin{array}{l}39.67 \\
(2.13)\end{array}$ & $\begin{array}{l}13.99 \\
(0.59)\end{array}$ & $\begin{array}{l}25.68 \\
(2.21)\end{array}$ & $\begin{array}{l}5.30 \\
(1.38)\end{array}$ & $\begin{array}{l}20.38 \\
(2.47)\end{array}$ \\
\hline Very Well & $\begin{array}{l}46.73 \\
(2.43)\end{array}$ & $\begin{array}{l}27.46 \\
(1.49)\end{array}$ & $\begin{array}{l}19.27 \\
(2.85)\end{array}$ & $\begin{array}{l}1.37 \\
(2.30)\end{array}$ & $\begin{array}{l}17.90 \\
(2.99)\end{array}$ \\
\hline Well & $\begin{array}{l}38.62 \\
(1.66)\end{array}$ & $\begin{array}{l}52.19 \\
(2.14)\end{array}$ & $\begin{array}{l}-13.57 \\
(2.71)\end{array}$ & $\begin{array}{l}-1.32 \\
(2.57)\end{array}$ & $\begin{array}{l}-12.25 \\
(2.18)\end{array}$ \\
\hline Not Well & $\begin{array}{l}59.77 \\
(2.46)\end{array}$ & $\begin{array}{l}67.90 \\
(2.85)\end{array}$ & $\begin{array}{l}-8.13 \\
(3.76)\end{array}$ & $\begin{array}{l}-3.42 \\
(3.50)\end{array}$ & $\begin{array}{l}-4.71 \\
(3.19)\end{array}$ \\
\hline Not At All & $\begin{array}{l}78.14 \\
(3.18) \\
\end{array}$ & $\begin{array}{l}77.20 \\
(3.76) \\
\end{array}$ & $\begin{array}{l}0.94 \\
(4.92) \\
\end{array}$ & $\begin{array}{l}-2.37 \\
(4.61)\end{array}$ & $\begin{array}{l}3.31 \\
(4.15) \\
\end{array}$ \\
\hline \multicolumn{6}{|c|}{ Wave 2} \\
\hline Best/Only & $\begin{array}{l}11.57 \\
(1.00)\end{array}$ & $\begin{array}{l}6.62 \\
(0.44)\end{array}$ & $\begin{array}{l}4.95 \\
(1.09)\end{array}$ & $\begin{array}{l}4.95 \\
(1.09)\end{array}$ & - \\
\hline Very Well & $\begin{array}{l}11.41 \\
(1.22)\end{array}$ & $\begin{array}{l}10.73 \\
(0.88)\end{array}$ & $\begin{array}{l}0.68 \\
(1.50)\end{array}$ & $\begin{array}{l}0.68 \\
(1.50)\end{array}$ & - \\
\hline Well & $\begin{array}{l}25.72 \\
(1.24)\end{array}$ & $\begin{array}{l}31.50 \\
(1.63)\end{array}$ & $\begin{array}{l}-5.78 \\
(2.05)\end{array}$ & $\begin{array}{l}-5.78 \\
(2.05)\end{array}$ & - \\
\hline Not Well & $\begin{array}{l}45.87 \\
(19.27)\end{array}$ & $\begin{array}{l}52.33 \\
(2.28)\end{array}$ & $\begin{array}{l}-6.46 \\
(19.40)\end{array}$ & $\begin{array}{l}-6.46 \\
(19.40)\end{array}$ & - \\
\hline Not At All & $\begin{array}{l}33.53 \\
(6.70)\end{array}$ & $\begin{array}{l}49.33 \\
(6.04)\end{array}$ & $\begin{array}{l}-15.80 \\
(9.02)\end{array}$ & $\begin{array}{l}-15.80 \\
(9.02)\end{array}$ & - \\
\hline \multicolumn{6}{|c|}{ Wave 3} \\
\hline Best/Only & $\begin{array}{l}4.43 \\
(0.48)\end{array}$ & $\begin{array}{l}3.40 \\
(0.28)\end{array}$ & $\begin{array}{l}1.03 \\
(0.56)\end{array}$ & $\begin{array}{l}1.03 \\
(0.56)\end{array}$ & - \\
\hline Very Well & $\begin{array}{l}7.51 \\
(0.79) \\
\end{array}$ & $\begin{array}{l}7.32 \\
(0.74)\end{array}$ & $\begin{array}{l}0.19 \\
(1.08) \\
\end{array}$ & $\begin{array}{l}0.19 \\
(1.08) \\
\end{array}$ & - \\
\hline Well & $\begin{array}{l}21.12 \\
(1.03)\end{array}$ & $\begin{array}{l}24.38 \\
(1.37)\end{array}$ & $\begin{array}{l}-3.26 \\
(1.71)\end{array}$ & $\begin{array}{l}-3.26 \\
(1.71)\end{array}$ & - \\
\hline Not Well & $\begin{array}{l}34.31 \\
(1.33)\end{array}$ & $\begin{array}{l}38.57 \\
(2.31)\end{array}$ & $\begin{array}{l}-4.26 \\
(2.67)\end{array}$ & $\begin{array}{l}-4.26 \\
(2.67)\end{array}$ & - \\
\hline Not At All & $\begin{array}{l}43.49 \\
(7.87)\end{array}$ & $\begin{array}{l}41.91 \\
(7.11)\end{array}$ & $\begin{array}{l}1.58 \\
(10.61)\end{array}$ & $\begin{array}{l}1.58 \\
(10.61)\end{array}$ & - \\
\hline
\end{tabular}

Note: Parentheses contain standard errors. 
Table 10

Decomposition of Unemployment Probability Gap between Asian and Non Asian Male Migrants

by Visa Category

\begin{tabular}{|c|c|c|c|c|c|}
\hline \multirow[t]{2}{*}{ Visa Category } & \multirow{2}{*}{$\begin{array}{l}\text { Average } \\
\text { Unemployment } \\
\text { Probability for } \\
\text { Asian Immigrants }\end{array}$} & \multirow[b]{2}{*}{$\begin{array}{l}\text { Average } \\
\text { Unemployment } \\
\text { Probability for } \\
\text { Non Asian } \\
\text { Immigrants }\end{array}$} & \multirow{2}{*}{$\begin{array}{l}\text { Unemployment } \\
\text { Probability } \\
\text { Gap }\end{array}$} & \multicolumn{2}{|c|}{ Decomposition of Gap } \\
\hline & & & & $\begin{array}{l}\text { Explained } \\
\text { Differences }\end{array}$ & $\begin{array}{l}\text { Unexplained } \\
\text { Differences }\end{array}$ \\
\hline \multicolumn{6}{|c|}{ Wave 1 } \\
\hline $\begin{array}{l}\text { Preferential } \\
\text { Family }\end{array}$ & $\begin{array}{l}45.75 \\
(1.19)\end{array}$ & $\begin{array}{l}34.58 \\
(1.05)\end{array}$ & $\begin{array}{l}11.17 \\
(1.59)\end{array}$ & $\begin{array}{l}5.96 \\
(1.45)\end{array}$ & $\begin{array}{l}5.21 \\
(1.55)\end{array}$ \\
\hline $\begin{array}{l}\text { Concessional } \\
\text { Family }\end{array}$ & $\begin{array}{l}44.20 \\
(1.11)\end{array}$ & $\begin{array}{l}28.87 \\
(1.28)\end{array}$ & $\begin{array}{l}15.33 \\
(1.69)\end{array}$ & $\begin{array}{l}7.26 \\
(1.64)\end{array}$ & $\begin{array}{l}8.07 \\
(1.51)\end{array}$ \\
\hline Independent & $\begin{array}{l}40.65 \\
(0.92)\end{array}$ & $\begin{array}{l}22.27 \\
(0.98)\end{array}$ & $\begin{array}{l}18.38 \\
(1.34)\end{array}$ & $\begin{array}{l}10.58 \\
(1.28)\end{array}$ & $\begin{array}{l}7.80 \\
(1.24)\end{array}$ \\
\hline Refugee & $\begin{array}{l}84.59 \\
(0.82) \\
\end{array}$ & $\begin{array}{l}81.14 \\
(1.14) \\
\end{array}$ & $\begin{array}{l}3.45 \\
(1.40) \\
\end{array}$ & $\begin{array}{l}-1.09 \\
(1.39) \\
\end{array}$ & $\begin{array}{l}4.54 \\
(1.14) \\
\end{array}$ \\
\hline Business/ENS & $\begin{array}{l}5.92 \\
(0.49) \\
\end{array}$ & $\begin{array}{l}1.61 \\
(0.16) \\
\end{array}$ & $\begin{array}{l}4.31 \\
(0.52) \\
\end{array}$ & $\begin{array}{l}2.91 \\
(0.36) \\
\end{array}$ & $\begin{array}{l}1.40 \\
(0.59) \\
\end{array}$ \\
\hline \multicolumn{6}{|c|}{ Wave 2} \\
\hline $\begin{array}{l}\text { Preferential } \\
\text { Family }\end{array}$ & $\begin{array}{l}28.97 \\
(0.92) \\
\end{array}$ & $\begin{array}{l}13.29 \\
(0.46) \\
\end{array}$ & $\begin{array}{l}15.68 \\
(1.03) \\
\end{array}$ & $\begin{array}{l}2.27 \\
(0.65) \\
\end{array}$ & $\begin{array}{l}13.41 \\
(1.03) \\
\end{array}$ \\
\hline $\begin{array}{l}\text { Concessional } \\
\text { Family }\end{array}$ & $\begin{array}{l}26.38 \\
(0.94)\end{array}$ & $\begin{array}{l}16.57 \\
(0.64)\end{array}$ & $\begin{array}{l}9.81 \\
(1.14)\end{array}$ & $\begin{array}{l}1.42 \\
(0.83)\end{array}$ & $\begin{array}{l}8.39 \\
(1.08)\end{array}$ \\
\hline Independent & $\begin{array}{l}16.44 \\
(0.67) \\
\end{array}$ & $\begin{array}{l}10.74 \\
(0.48) \\
\end{array}$ & $\begin{array}{l}5.70 \\
(0.82) \\
\end{array}$ & $\begin{array}{l}2.63 \\
(0.64) \\
\end{array}$ & $\begin{array}{l}3.07 \\
(0.79) \\
\end{array}$ \\
\hline Refugee & $\begin{array}{l}66.63 \\
(0.98)\end{array}$ & $\begin{array}{l}48.39 \\
(1.31)\end{array}$ & $\begin{array}{l}18.24 \\
(1.64)\end{array}$ & $\begin{array}{l}-3.20 \\
(1.62)\end{array}$ & $\begin{array}{l}21.44 \\
(1.37)\end{array}$ \\
\hline Business/ENS & $\begin{array}{l}6.80 \\
(0.52) \\
\end{array}$ & $\begin{array}{l}0.87 \\
(0.06) \\
\end{array}$ & $\begin{array}{l}5.93 \\
(0.52) \\
\end{array}$ & $\begin{array}{l}0.64 \\
(0.13) \\
\end{array}$ & $\begin{array}{l}5.29 \\
(0.53) \\
\end{array}$ \\
\hline \multicolumn{6}{|c|}{ Wave 3} \\
\hline $\begin{array}{l}\text { Preferential } \\
\text { Family }\end{array}$ & $\begin{array}{l}15.11 \\
(0.84) \\
\end{array}$ & $\begin{array}{l}7.32 \\
(0.48)\end{array}$ & $\begin{array}{l}7.79 \\
(0.97)\end{array}$ & $\begin{array}{l}1.23 \\
(0.78)\end{array}$ & $\begin{array}{l}6.56 \\
(1.04)\end{array}$ \\
\hline $\begin{array}{l}\text { Concessional } \\
\text { Family }\end{array}$ & $\begin{array}{l}13.66 \\
(0.65)\end{array}$ & $\begin{array}{l}8.01 \\
(0.61)\end{array}$ & $\begin{array}{l}5.65 \\
(0.89)\end{array}$ & $\begin{array}{l}0.86 \\
(0.81)\end{array}$ & $\begin{array}{l}4.79 \\
(0.85)\end{array}$ \\
\hline Independent & $\begin{array}{l}8.43 \\
(0.46)\end{array}$ & $\begin{array}{l}2.50 \\
(0.28)\end{array}$ & $\begin{array}{l}5.93 \\
(0.54)\end{array}$ & $\begin{array}{l}1.41 \\
(0.42)\end{array}$ & $\begin{array}{l}4.52 \\
(0.55)\end{array}$ \\
\hline Refugee & $\begin{array}{l}38.61 \\
(1.27)\end{array}$ & $\begin{array}{l}33.43 \\
(1.49)\end{array}$ & $\begin{array}{l}5.18 \\
(1.96)\end{array}$ & $\begin{array}{l}-2.68 \\
(2.00)\end{array}$ & $\begin{array}{l}7.86 \\
(1.83)\end{array}$ \\
\hline Business/ENS & $\begin{array}{l}13.75 \\
(1.04) \\
\end{array}$ & $\begin{array}{l}4.87 \\
(0.48) \\
\end{array}$ & $\begin{array}{l}8.88 \\
(1.15) \\
\end{array}$ & $\begin{array}{l}6.21 \\
(1.06) \\
\end{array}$ & $\begin{array}{l}2.67 \\
(1.40) \\
\end{array}$ \\
\hline
\end{tabular}

Note: Parentheses contain standard errors. 
Table 11

Decomposition of UnemploymentProbability Gap between Asian and Non Asian Female Migrants by Visa Category

\begin{tabular}{|c|c|c|c|c|c|}
\hline \multirow[t]{2}{*}{ Visa Category } & \multirow{2}{*}{$\begin{array}{l}\text { Average } \\
\text { Unemployment } \\
\text { Probability for } \\
\text { Asian Immigrants }\end{array}$} & \multirow{2}{*}{$\begin{array}{l}\text { Average } \\
\text { Unemployment } \\
\text { Probability for } \\
\text { Non Asian } \\
\text { Immigrants }\end{array}$} & \multirow{2}{*}{$\begin{array}{l}\text { Unemployment } \\
\text { Probability } \\
\text { Gap }\end{array}$} & \multicolumn{2}{|c|}{ Decomposition of Gap } \\
\hline & & & & $\begin{array}{l}\text { Explained } \\
\text { Differences }\end{array}$ & $\begin{array}{l}\text { Unexplained } \\
\text { Differences }\end{array}$ \\
\hline \multicolumn{6}{|c|}{ Wave 1} \\
\hline $\begin{array}{l}\text { Preferential } \\
\text { Family }\end{array}$ & $\begin{array}{l}43.33 \\
(1.41)\end{array}$ & $\begin{array}{l}32.06 \\
(1.53)\end{array}$ & $\begin{array}{l}11.27 \\
(2.08)\end{array}$ & $\begin{array}{l}12.51 \\
(2.12)\end{array}$ & $\begin{array}{l}-1.24 \\
(2.04)\end{array}$ \\
\hline $\begin{array}{l}\text { Concessional } \\
\text { Family }\end{array}$ & $\begin{array}{l}48.30 \\
(2.34) \\
\end{array}$ & $\begin{array}{l}31.79 \\
(2.91) \\
\end{array}$ & $\begin{array}{l}16.51 \\
(3.73) \\
\end{array}$ & $\begin{array}{l}15.83 \\
(3.86) \\
\end{array}$ & $\begin{array}{l}0.68 \\
(3.45) \\
\end{array}$ \\
\hline Independent & $\begin{array}{l}37.79 \\
(2.09) \\
\end{array}$ & $\begin{array}{l}20.60 \\
(1.70)\end{array}$ & $\begin{array}{l}17.19 \\
(2.69)\end{array}$ & $\begin{array}{l}7.27 \\
(2.43) \\
\end{array}$ & $\begin{array}{l}9.92 \\
(2.72) \\
\end{array}$ \\
\hline Refugee & $\begin{array}{l}91.59 \\
(0.64) \\
\end{array}$ & $\begin{array}{l}86.17 \\
(1.79) \\
\end{array}$ & $\begin{array}{l}5.42 \\
(1.90) \\
\end{array}$ & $\begin{array}{l}-1.57 \\
(2.37) \\
\end{array}$ & $\begin{array}{l}6.99 \\
(1.69) \\
\end{array}$ \\
\hline Business/ENS & $\begin{array}{l}36.64 \\
(3.08) \\
\end{array}$ & $\begin{array}{l}18.77 \\
(1.84) \\
\end{array}$ & \begin{tabular}{|l|}
17.87 \\
$(3.59)$ \\
\end{tabular} & $\begin{array}{l}20.24 \\
(4.33) \\
\end{array}$ & $\begin{array}{l}-2.37 \\
(4.99) \\
\end{array}$ \\
\hline \multicolumn{6}{|c|}{ Wave 2} \\
\hline $\begin{array}{l}\text { Preferential } \\
\text { Family }\end{array}$ & $\begin{array}{l}26.80 \\
(1.26)\end{array}$ & $\begin{array}{l}21.17 \\
(1.20)\end{array}$ & \begin{tabular}{|l}
5.63 \\
$(1.74)$ \\
\end{tabular} & $\begin{array}{l}5.63 \\
(1.74)\end{array}$ & - \\
\hline $\begin{array}{l}\text { Concessional } \\
\text { Family } \\
\end{array}$ & $\begin{array}{l}23.05 \\
(1.83) \\
\end{array}$ & $\begin{array}{l}16.17 \\
(2.36) \\
\end{array}$ & $\begin{array}{l}6.88 \\
(2.99) \\
\end{array}$ & $\begin{array}{l}6.88 \\
(2.99) \\
\end{array}$ & - \\
\hline Independent & $\begin{array}{l}10.36 \\
(1.07) \\
\end{array}$ & $\begin{array}{l}8.62 \\
(0.97) \\
\end{array}$ & $\begin{array}{l}1.74 \\
(1.44) \\
\end{array}$ & $\begin{array}{l}1.74 \\
(1.44) \\
\end{array}$ & - \\
\hline Refugee & $\begin{array}{l}49.45 \\
(2.02)\end{array}$ & $\begin{array}{l}55.26 \\
(2.23)\end{array}$ & $\begin{array}{l}-5.81 \\
(3.01)\end{array}$ & $\begin{array}{l}-5.81 \\
(3.01)\end{array}$ & - \\
\hline Business/ENS & $\begin{array}{l}5.12 \\
(0.82) \\
\end{array}$ & $\begin{array}{l}1.66 \\
(0.25) \\
\end{array}$ & \begin{tabular}{|l|}
3.46 \\
$(0.86)$ \\
\end{tabular} & $\begin{array}{l}3.46 \\
(0.86) \\
\end{array}$ & - \\
\hline \multicolumn{6}{|c|}{ Wave 3} \\
\hline $\begin{array}{l}\text { Preferential } \\
\text { Family }\end{array}$ & $\begin{array}{l}19.39 \\
(0.89) \\
\end{array}$ & $\begin{array}{l}13.74 \\
(0.84) \\
\end{array}$ & \begin{tabular}{|l}
5.65 \\
$(1.22)$
\end{tabular} & $\begin{array}{l}5.65 \\
(1.22)\end{array}$ & - \\
\hline $\begin{array}{l}\text { Concessional } \\
\text { Family }\end{array}$ & $\begin{array}{l}14.40 \\
(1.13) \\
\end{array}$ & $\begin{array}{l}11.93 \\
(1.69) \\
\end{array}$ & $\begin{array}{l}2.47 \\
(2.03) \\
\end{array}$ & $\begin{array}{l}2.47 \\
(2.03) \\
\end{array}$ & - \\
\hline Independent & $\begin{array}{l}1.74 \\
(0.24)\end{array}$ & $\begin{array}{l}1.67 \\
(0.26)\end{array}$ & $\begin{array}{l}0.07 \\
(0.35)\end{array}$ & $\begin{array}{l}0.07 \\
(0.35)\end{array}$ & - \\
\hline Refugee & $\begin{array}{l}40.03 \\
(2.01) \\
\end{array}$ & $\begin{array}{l}44.05 \\
(1.75) \\
\end{array}$ & $\begin{array}{l}-4.02 \\
(2.67) \\
\end{array}$ & $\begin{array}{l}-4.02 \\
(2.67)\end{array}$ & - \\
\hline Business/ENS & $\begin{array}{l}14.99 \\
(2.84) \\
\end{array}$ & $\begin{array}{l}3.07 \\
(0.47) \\
\end{array}$ & $\begin{array}{l}11.92 \\
(2.88) \\
\end{array}$ & $\begin{array}{l}11.92 \\
(2.88) \\
\end{array}$ & - \\
\hline
\end{tabular}

Note: Parentheses contain standard errors. 
Appendix Table A1

Estimates of Probit Model for Males

\begin{tabular}{|c|c|c|c|c|c|c|}
\hline & \multicolumn{2}{|l|}{ Wave 1} & \multicolumn{2}{|l|}{ Wave 2} & \multicolumn{2}{|l|}{ Wave 3} \\
\hline & Coefficient & $\begin{array}{l}\text { Standard } \\
\text { Error }\end{array}$ & Coefficient & $\begin{array}{l}\text { Standard } \\
\text { Error }\end{array}$ & Coefficient & $\begin{array}{l}\text { Standard } \\
\text { Error }\end{array}$ \\
\hline \multicolumn{7}{|l|}{ Demographic } \\
\hline Age & 0.0303 & 0.0063 & 0.0226 & 0.0072 & 0.0286 & 0.0083 \\
\hline Married & 0.1161 & 0.1207 & 0.1725 & 0.1562 & -0.3864 & 0.1918 \\
\hline Visited Australia prior to migration & -0.0441 & 0.1050 & -0.3324 & 0.1271 & -0.2142 & 0.1607 \\
\hline \multicolumn{7}{|l|}{ Visa Category [Business Skills/ENT] } \\
\hline Preferential Family & 1.7759 & 0.2386 & 1.3415 & 0.2965 & (a) & \\
\hline Concessional Family & 1.6158 & 0.2355 & 1.2813 & 0.2924 & -0.0683 & 0.1896 \\
\hline Independent & 1.6775 & 0.2298 & 1.2462 & 0.2946 & -0.3915 & 0.2457 \\
\hline Refugee & 2.6535 & 0.2665 & 2.0323 & 0.3110 & 0.5632 & 0.1967 \\
\hline \multicolumn{7}{|l|}{ Education [High School or less] } \\
\hline Graduates & 0.0271 & 0.1465 & 0.2154 & 0.1598 & -0.1595 & 0.1836 \\
\hline Technical/Trade & -0.0916 & 0.1330 & 0.0965 & 0.1519 & -0.0446 & 0.1788 \\
\hline \multicolumn{7}{|l|}{ English [Not at all] } \\
\hline Only or Best & -0.8745 & 0.2445 & -0.4297 & 0.3908 & -1.0571 & 0.2176 \\
\hline Very Well & -0.3808 & 0.2572 & -0.4306 & 0.4143 & -0.2364 & 0.2143 \\
\hline Well & -0.1197 & 0.2404 & -0.1019 & 0.3858 & -0.4519 & 0.1831 \\
\hline Poor & -0.0733 & 0.2402 & 0.0301 & 0.3841 & (a) & \\
\hline \multicolumn{7}{|l|}{ State of Residence [NSW] } \\
\hline Victoria & 0.3848 & 0.1199 & 0.0466 & 0.1367 & 0.4103 & 0.1616 \\
\hline QLD & -0.4062 & 0.1759 & 0.0977 & 0.1764 & -0.0562 & 0.2582 \\
\hline SA & 0.4960 & 0.1722 & 0.3689 & 0.1982 & 0.9265 & 0.2381 \\
\hline WA & -0.1674 & 0.1518 & -0.0424 & 0.1797 & 0.1311 & 0.2170 \\
\hline NT & -0.7250 & 0.6203 & (a) & & (a) & \\
\hline ACT & 0.0247 & 0.2917 & 0.2558 & 0.2874 & (a) & \\
\hline Tasmania & -0.2860 & 0.4435 & (a) & & 0.1661 & 0.3987 \\
\hline Asian Dummy & 0.5855 & 0.5287 & 1.0751 & 0.7255 & 0.5850 & 0.4999 \\
\hline Age x Asian Dummy & 0.0024 & 0.0088 & 0.0017 & 0.0096 & -0.0045 & 0.0114 \\
\hline Married x Asian Dummy & -0.0370 & 0.1629 & 0.0956 & 0.2051 & 0.2812 & 0.2548 \\
\hline $\begin{array}{l}\text { Visited Australia prior to migration } \mathrm{x} \text { Asian } \\
\text { Dummy }\end{array}$ & -0.4105 & 0.1487 & -0.2195 & 0.1788 & -0.4497 & 0.2313 \\
\hline Preferential Family x Asian Dummy & 0.0719 & 0.3232 & -0.3175 & 0.3716 & & \\
\hline Concessional Family x Asian Dummy & -0.0910 & 0.3135 & -0.4654 & 0.3575 & -0.1233 & 0.2453 \\
\hline Independent x Asian Dummy & -0.0712 & 0.3122 & -0.5886 & 0.3679 & 0.0756 & 0.3075 \\
\hline Refugees x Asian Dummy & 0.0442 & 0.3638 & -0.3136 & 0.3889 & -0.1502 & 0.2542 \\
\hline Graduates x Asian Dummy & 0.4886 & 0.2083 & -0.0425 & 0.2178 & 0.2379 & 0.2398 \\
\hline Technical/Trade x Asian Dummy & 0.0453 & 0.1980 & -0.3013 & 0.2124 & -0.1695 & 0.2437 \\
\hline English Only or Best x Asian Dummy & -0.2903 & 0.3509 & -0.5170 & 0.5176 & 0.3655 & 0.3020 \\
\hline English Very Well x Asian Dummy & -0.6388 & 0.3583 & -0.0604 & 0.5315 & -0.3770 & 0.2878 \\
\hline English Well x Asian Dummy & -0.7250 & 0.3333 & -0.3303 & 0.4976 & -0.0478 & 0.2279 \\
\hline English Poor x Asian Dummy & -0.6944 & 0.3270 & -0.1726 & 0.4927 & (a) & \\
\hline Victoria x Asian Dummy & -0.0077 & 0.1579 & 0.0111 & 0.1749 & -0.3653 & 0.2067 \\
\hline QLD x Asian Dummy & 0.1516 & 0.2567 & -0.1926 & 0.2671 & -0.1848 & 0.3479 \\
\hline SA x Asian Dummy & -0.3968 & 0.3157 & -0.8839 & 0.4116 & -0.7762 & 0.4240 \\
\hline WA x Asian Dummy & 0.6375 & 0.2254 & -0.0179 & 0.2692 & -0.4937 & 0.3296 \\
\hline NT x Asian Dummy & 1.1012 & 0.7569 & (a) & & (a) & \\
\hline ACT x Asian Dummy & -0.2138 & 0.4042 & -0.3924 & 0.3899 & (a) & \\
\hline Tasmania x Asian Dummy & -0.9130 & 0.7946 & (a) & & -0.8225 & 0.7621 \\
\hline Constant & -2.8788 & 0.3931 & -3.0951 & 0.5540 & -1.7207 & 0.3828 \\
\hline Sample Size & \multicolumn{2}{|l|}{2168} & \multicolumn{2}{|l|}{2035} & \multicolumn{2}{|l|}{1749} \\
\hline Wald $\chi^{2}$ (d.f) & \multicolumn{2}{|l|}{$585.57 * *$} & \multicolumn{2}{|l|}{$376.49 * *$} & \multicolumn{2}{|l|}{$224.28 * *$} \\
\hline Pseudo R ${ }^{2}$ & \multicolumn{2}{|l|}{0.28} & \multicolumn{2}{|l|}{0.23} & \multicolumn{2}{|l|}{0.21} \\
\hline
\end{tabular}

Note: The default category is within brackets. (a) indicates that variable is not included due to multicollinearity.

** indicates significant at $1 \%$ level. 
Appendix Table A2

Estimates of Probit Model for Females

\begin{tabular}{|c|c|c|c|c|c|c|}
\hline & \multicolumn{2}{|l|}{ Wave 1} & \multicolumn{2}{|l|}{ Wave 2} & \multicolumn{2}{|l|}{ Wave 3} \\
\hline & Coefficient & $\begin{array}{l}\text { Standard } \\
\text { Error }\end{array}$ & Coefficient & $\begin{array}{l}\text { Standard } \\
\text { Error }\end{array}$ & Coefficient & $\begin{array}{l}\text { Standard } \\
\text { Error }\end{array}$ \\
\hline \multicolumn{7}{|l|}{ Demographic } \\
\hline Age & 0.0031 & 0.0094 & 0.0102 & 0.0105 & 0.0113 & 0.0123 \\
\hline Married & 0.1006 & 0.1675 & 0.2277 & 0.2288 & -0.4161 & 0.2472 \\
\hline Visited Australia prior to migration & -0.4862 & 0.1565 & -0.6074 & 0.1964 & -0.2395 & 0.2279 \\
\hline \multicolumn{7}{|l|}{ Visa Category [Business Skills/ENT] } \\
\hline Preferential Family & (a) & & 0.3976 & 0.4467 & (a) & \\
\hline Concessional Family & 0.3715 & 0.2329 & 0.6458 & 0.4637 & 0.3497 & 0.3116 \\
\hline Independent & -0.1263 & 0.1863 & 0.2070 & 0.4528 & -0.3975 & 0.3264 \\
\hline Refugee & 0.8174 & 0.2928 & 0.3212 & 0.4982 & 0.4814 & 0.2693 \\
\hline \multicolumn{7}{|l|}{ Education [High School or less] } \\
\hline Graduates & -0.0602 & 0.2021 & -0.6035 & 0.2418 & -0.4544 & 0.2729 \\
\hline Technical/Trade & -0.0026 & 0.2076 & -0.6017 & 0.2172 & 0.0275 & 0.2384 \\
\hline \multicolumn{7}{|l|}{ English [Not at all] } \\
\hline Only or Best & -0.9977 & 0.4570 & -0.5884 & 0.5976 & -1.1762 & 0.7857 \\
\hline Very Well & -0.6571 & 0.4645 & -0.3362 & 0.5981 & -0.4670 & 0.7860 \\
\hline Well & -0.0315 & 0.4577 & 0.3135 & 0.5660 & 0.0033 & 0.7586 \\
\hline Poor & -0.0550 & 0.4589 & 0.3795 & 0.5420 & 0.0765 & 0.7600 \\
\hline \multicolumn{7}{|l|}{ State of Residence [NSW] } \\
\hline Victoria & 0.5603 & 0.1681 & 0.3686 & 0.1947 & 0.0918 & 0.2512 \\
\hline QLD & -0.3803 & 0.2455 & -0.0988 & 0.2840 & -0.0008 & 0.2940 \\
\hline SA & 0.3505 & 0.3209 & 0.6095 & 0.3598 & -0.1032 & 0.4314 \\
\hline WA & 0.1746 & 0.2795 & -0.0865 & 0.3337 & 0.3390 & 0.3253 \\
\hline NT & -0.6362 & 0.4266 & (a) & & (a) & \\
\hline $\mathrm{ACT}$ & -0.4780 & 0.4410 & -0.0937 & 0.5434 & 0.3493 & 0.4724 \\
\hline Tasmania & -0.5901 & 0.7755 & (a) & & (a) & \\
\hline Asian Dummy & -0.1829 & 0.6939 & -1.7491 & 1.1998 & 0.1660 & 1.2246 \\
\hline Age x Asian Dummy & 0.0031 & 0.0142 & 0.0181 & 0.0157 & 0.0060 & 0.0174 \\
\hline Married x Asian Dummy & 0.3252 & 0.2374 & -0.2230 & 0.3066 & 0.6158 & 0.3549 \\
\hline $\begin{array}{l}\text { Visited Australia prior to migration } \mathrm{x} \text { Asian } \\
\text { Dummy }\end{array}$ & -0.3542 & 0.2117 & 0.0599 & 0.2507 & -0.3101 & 0.3172 \\
\hline Preferential Family x Asian Dummy & (a) & & 1.1771 & 0.6277 & (a) & \\
\hline Conces sional Family x Asian Dummy & -0.1442 & 0.3129 & 0.6032 & 0.6476 & -0.4057 & 0.4201 \\
\hline Independent x Asian Dummy & 0.1984 & 0.2718 & 0.7223 & 0.6620 & (a) & \\
\hline Refugees x Asian Dummy & 0.3257 & 0.4251 & 1.6466 & 0.6963 & -0.1011 & 0.3701 \\
\hline Graduates x Asian Dummy & 0.0297 & 0.2843 & 0.7530 & 0.3193 & -0.1163 & 0.3719 \\
\hline Technical/Trade x Asian Dummy & -0.1871 & 0.2977 & 0.5111 & 0.3284 & -0.3545 & 0.3419 \\
\hline English Only or Best x Asian Dummy & 0.7382 & 0.5830 & 0.4265 & 0.8096 & 0.4008 & 1.0438 \\
\hline English Very Well x Asian Dummy & 0.6017 & 0.5893 & -0.1508 & 0.8236 & -0.3488 & 1.0466 \\
\hline English Well x Asian Dummy & -0.2500 & 0.5650 & -0.2547 & 0.7708 & -0.3944 & 0.9987 \\
\hline English Poor x Asian Dummy & -0.1485 & 0.5582 & 0.0082 & 0.7558 & -0.3538 & 0.9911 \\
\hline Victoria x Asian Dummy & -0.1734 & 0.2258 & -0.0891 & 0.2622 & -0.2589 & 0.3268 \\
\hline QLD x Asian Dummy & 0.0952 & 0.3839 & 0.1785 & 0.4026 & -0.4773 & 0.4683 \\
\hline SA x Asian Dummy & -0.3470 & 0.5031 & 0.0283 & 0.5353 & -0.8317 & 0.7181 \\
\hline WA x Asian Dummy & 0.0189 & 0.3765 & -0.3189 & 0.4495 & -0.6652 & 0.4429 \\
\hline NT x Asian Dummy & (a) & & (a) & & (a) & \\
\hline ACT x Asian Dummy & 0.7414 & 0.5650 & 0.4070 & 0.7069 & -0.2139 & 0.6309 \\
\hline Tasmania x Asian Dummy & (a) & & (a) & & (a) & \\
\hline Constant & 0.0268 & 0.5551 & -1.1671 & 0.8582 & -0.7302 & 0.9185 \\
\hline Sample Size & \multicolumn{2}{|l|}{904} & \multicolumn{2}{|l|}{830} & \multicolumn{2}{|l|}{677} \\
\hline Wald $\chi^{2}$ (d.f) & \multicolumn{2}{|l|}{$224.51 * *$} & \multicolumn{2}{|l|}{$180.76^{* *}$} & \multicolumn{2}{|l|}{$118.31^{* * *}$} \\
\hline Pseudo R ${ }^{2}$ & \multicolumn{2}{|l|}{0.21} & \multicolumn{2}{|l|}{0.24} & \multicolumn{2}{|l|}{0.20} \\
\hline
\end{tabular}

Note: The default category is within brackets. (a) indicates that variable is not included due to mult icollinearity. ** indicates significant at $1 \%$ level. 
Appendix Table A3

Estimates of Probit Model for Females (without Asian Dummies)

\begin{tabular}{|l|l|l|l|l|}
\hline & Wave 2 & Wave 3 \\
\hline & Coefficient & $\begin{array}{l}\text { Standard } \\
\text { Error }\end{array}$ & Coefficient & $\begin{array}{l}\text { Standard } \\
\text { Error }\end{array}$ \\
\hline Demographic & & & & \\
\hline Age & 0.0145 & 0.0076 & 0.0133 & 0.0084 \\
\hline Married & 0.0956 & 0.1482 & 0.0006 & 0.1755 \\
\hline Visited Australia prior to migration & -0.6060 & 0.1191 & -0.4500 & 0.1483 \\
\hline Visa Category [Business Skills/ENT] & & & & \\
\hline Preferential Family & 1.0823 & 0.3281 & $(\mathrm{a})$ & \\
\hline Concessional Family & 1.0388 & 0.3394 & 0.0947 & 0.2060 \\
\hline Independent & 0.6227 & 0.3470 & -0.7202 & 0.2968 \\
\hline Refugee & 1.2600 & 0.3517 & 0.3956 & 0.1781 \\
\hline Education [High School or less] & & & & \\
\hline Graduates & -0.1348 & 0.1541 & -0.5360 & 0.1887 \\
\hline Technical/Trade & -0.3920 & 0.1584 & -0.1410 & 0.1670 \\
\hline English [Not at all] & & & & \\
\hline Only or Best & -0.3752 & 0.4200 & -0.0163 & 0.5220 \\
\hline Very Well & -0.3992 & 0.4298 & -0.7034 & 0.5217 \\
\hline Well & 0.1278 & 0.4061 & -0.2846 & 0.5023 \\
\hline Poor & 0.3299 & 0.4001 & -0.1926 & 0.4977 \\
\hline State of Residence [NSW] & & & & \\
\hline Victoria & 0.2949 & 0.1287 & -0.0863 & 0.1545 \\
\hline QLD & -0.0293 & 0.1997 & -0.2419 & 0.2160 \\
\hline SA & 0.6216 & 0.2638 & -0.3962 & 0.3510 \\
\hline WA & -0.1824 & 0.2256 & -0.0511 & 0.2123 \\
\hline NT & -0.3007 & 0.5659 & $(\mathrm{a})$ & \\
\hline ACT & 0.1667 & 0.3461 & 0.2096 & 0.3203 \\
\hline Tasmania & $(\mathrm{a})$ & & $(\mathrm{a})$ & \\
\hline Constant & -0.9417 & 0.6107 & -0.5420 & 0.6074 \\
\hline Sample Size & 830 & & 733 & \\
\hline Wald $\chi^{2}$ (d.f) & $157.05 * *(\mathrm{df}=19)$ & $104.16 * *(\mathrm{df}=17)$ \\
\hline Pseudo R & 0.2131 & & 0.1963 & \\
\hline Note: The & & & \\
\hline
\end{tabular}

Note: The default category is within brackets. (a) indicates that variable is not included due to multicollinearity. ** indicates significant at $1 \%$ level. 
Appendix Table A4

Estimates of Marginal effects

\begin{tabular}{|c|c|c|c|c|c|c|}
\hline & \multicolumn{3}{|c|}{ Males } & \multicolumn{3}{|c|}{ Females } \\
\hline & Wave1 & Wave 2 & Wave 3 & Wave 1 & Wave 2 & Wave 3 \\
\hline \multicolumn{7}{|l|}{ Demographic } \\
\hline Age & $1.06^{* *}$ & $0.53 * *$ & $0.42 * *$ & 0.18 & $0.35+$ & 0.24 \\
\hline Married & 4.00 & 3.84 & $-6.87 *$ & 5.13 & 2.28 & 0.01 \\
\hline Visited Australia prior to migration & -1.54 & $-7.68 *$ & -3.10 & -18.93 & -15.06 & $-8.10^{* *}$ \\
\hline \multicolumn{7}{|l|}{ Visa Category [Business Skills/ENT] } \\
\hline Preferential Family & $62.37 * *$ & $40.42 *$ & (a) & (a) & $27.10^{*}$ & (a) \\
\hline Concessional Family & $58.06^{* *}$ & $39.61 * *$ & -0.98 & 12.81 & $33.37^{*}$ & 1.78 \\
\hline Independent & $59.77 * *$ & $37.86^{* *}$ & -4.95 & -4.84 & $17.86+$ & $-9.57 *$ \\
\hline Refugee & $76.74 * *$ & $67.02^{* *}$ & $10.86^{*}$ & $34.59^{*}$ & $42.29 * *$ & $8.53 *$ \\
\hline \multicolumn{7}{|l|}{ Education [High School or less] } \\
\hline Graduates & 0.95 & 5.13 & -2.31 & -0.95 & -3.27 & $-9.37 * *$ \\
\hline Technical/Trade & -3.18 & 2.30 & -0.65 & -1.17 & $-8.70 *$ & -2.44 \\
\hline \multicolumn{7}{|l|}{ English [Not at all] } \\
\hline Only or Best & $-27.76^{* *}$ & -9.34 & $-12.40^{* *}$ & $-35.33 *$ & -8.59 & $-14.19^{*}$ \\
\hline Very Well & -12.34 & -8.57 & -3.13 & -33.03 & -8.52 & -9.19 \\
\hline Well & -4.13 & -2.34 & $-6.03^{*}$ & -4.08 & 3.19 & -4.85 \\
\hline Poor & -2.54 & 0.71 & (a) & -0.17 & 8.93 & -3.19 \\
\hline \multicolumn{7}{|l|}{ State of Residence [NSW] } \\
\hline Victoria & $14.02^{*}$ & 1.10 & $7.01^{*}$ & (a) & $7.72 *$ & -1.52 \\
\hline QLD & $-12.93^{*}$ & 2.38 & -0.80 & (a) & -0.70 & -3.89 \\
\hline SA & $18.83^{*}$ & $10.13+$ & $22.59 * *$ & 8.18 & $19.15^{*}$ & -5.63 \\
\hline WA & -05.68 & -0.98 & 2.07 & 2.38 & -4.12 & -0.90 \\
\hline NT & -19.83 & (a) & (a) & (a) & -6.28 & (a) \\
\hline ACT & 0.87 & 6.76 & (a) & -21.23 & 4.38 & 4.27 \\
\hline Tasmania & -9.24 & (a) & 2.74 & -24.32 & (a) & (a) \\
\hline Asian Dummy & 20.41 & 25.83 & 8.94 & -1.22 & & \\
\hline Age x Asian Dummy & 0.08 & 0.03 & -0.06 & -0.08 & & \\
\hline Married x Asian Dummy & -01.29 & 2.27 & 4.33 & 11.06 & & \\
\hline $\begin{array}{l}\text { Visited Australia prior to migration } \mathrm{x} \text { Asian } \\
\text { Dummy }\end{array}$ & $-13.29 *$ & -4.77 & $-5.33^{*}$ & $\begin{array}{c}-13.14+ \\
-14\end{array}$ & & \\
\hline Preferential Family x Asian Dummy & 2.55 & -6.53 & (a) & (a) & & \\
\hline Concessional Family x Asian Dummy & -3.13 & -9.98 & -1.70 & -3.19 & & \\
\hline Independent $\mathrm{x}$ Asian Dummy & -2.46 & $-10.72+$ & 1.16 & 9.44 & & \\
\hline Refugees x Asian Dummy & 1.56 & -6.38 & -2.02 & 11.01 & & \\
\hline Graduates x Asian Dummy & $18.02 *$ & -0.98 & 3.86 & -1.40 & & \\
\hline Technical/Trade x Asian Dummy & 1.60 & -6.28 & -2.28 & -7.99 & & \\
\hline English Only or Best x Asian Dummy & -9.49 & -9.54 & 6.64 & 30.76 & & \\
\hline English Very Well x Asian Dummy & $-18.82+$ & -1.38 & -4.45 & 23.83 & & \\
\hline English Well x Asian Dummy & $-21.47^{*}$ & -6.91 & -0.68 & -6.74 & & \\
\hline English Poor x Asian Dummy & $-20.57 *$ & -3.79 & (a) & -6.86 & & \\
\hline Victoria x Asian Dummy & -0.27 & 0.26 & $-4.44+$ & (a) & & \\
\hline QLD x Asian Dummy & 5.49 & -4.11 & -2.41 & (a) & & \\
\hline SA x Asian Dummy & -12.35 & $-12.57^{*}$ & $-6.58+$ & -11.55 & & \\
\hline WA x Asian Dummy & $24.44 *$ & -4.17 & -5.24 & 1.40 & & \\
\hline NT x Asian Dummy & 41.78 & (a) & (a) & (a) & & \\
\hline ACT x Asian Dummy & -7.06 & -7.45 & (a) & 31.47 & & \\
\hline Tasmania x Asian Dummy & -22.88 & (a) & -6.67 & (a) & & \\
\hline Sample size & 2168 & 2035 & 1749 & 904 & 830 & 733 \\
\hline
\end{tabular}

Note2: (1) (a) indicates that variable not included in the Probit model due to multicollinearity.

(2) The marginal effects for females for Waves 2 and 3 are based on Probit model without Asian dummies.

(3) Note: **,* and + indicates significant respectively at 1,5 and $10 \%$ levels. 